\title{
International Olympic Committee (IOC) Consensus Statement on Relative Energy Deficiency in Sport (RED-S): 2018 Update
}

\author{
Margo Mountjoy \\ McMaster University
}

Kathryn E. Ackerman

Boston Children's Hospital and

Massachusetts General Hospital

Constance Lebrun

University of Alberta

Nanna Meyer

University of Colorado

\author{
Jorunn Sundgot-Borgen \\ The Norwegian School \\ of Sport Sciences
}

\author{
Cheri Blauwet \\ Harvard Medical School and \\ Spaulding Rehabilitation Hospital/ \\ Brigham and Women's Hospital \\ Bronwen Lundy \\ Australian Institute of Sport \\ Roberta Sherman \\ Bloomington, IN
}
Richard Budgett
IOC Medical and

\author{
Scientific Department
}

\author{
Louise Burke \\ Australian Institute of Sport and \\ Mary MacKillop Institute \\ for Health Research \\ Naama Constantini \\ Hebrew University \\ Anna Melin \\ University of Copenhagen \\ Adam S. Tenforde \\ Harvard Medical School and \\ Spaulding Rehabilitation Hospital
}

\section{Monica Klungland Torstveit University of Agder}

Keywords: amenorrhea, disordered eating, female athlete triad, low bone mineral density, low energy availability, low testosterone, relative energy deficiency in sport (RED-S)

In 2014, the International Olympic Committee (IOC) published a consensus statement entitled "Beyond the Female Athlete Triad: Relative Energy Deficiency in Sport (RED-S)". The syndrome of RED-S refers to: "impaired physiological functioning caused by relative energy deficiency, and includes but is not limited to impairments of metabolic rate, menstrual function, bone health, immunity, protein synthesis, and cardiovascular health." The aetiological factor of this syndrome is low energy availability (LEA) (Mountjoy et al., 2014).
The publication of the RED-S consensus statement stimulated activity in the field of Female Athlete Triad science, including some initial controversy (De Souza, Williams, et al., 2014; Mountjoy, Sundgot-Borgen, Burke, Carter, Constantini, Lebrun, Meyer, Sherman, Steffen, Budgett, \& Ljungqvist, 2015) followed by numerous scientific publications addressing:

1. The health parameters identified in the RED-S conceptual model (Figure 1) (Constantini, 2002; Mountjoy et al., 2014)

\footnotetext{
Mountjoy is with the Dept. of Family Medicine, Michael G. DeGroote School of Medicine, McMaster University, Hamilton, Canada. Sundgot-Borgen is with the Dept. of Sports Medicine, The Norwegian School of Sport Sciences, Oslo, Norway. Lundy and Burke are with the Sports Nutrition, Australian Institute of Sport, Belconnen, Australia. Burke is also with the Centre for Exercise and Nutrition, Mary MacKillop Institute for Health Research, Melbourne, Australia. Ackerman is with the Divisions of Sports Medicine and Endocrinology, Boston Children's Hospital, Massachusetts, MA; and also with the Neuroendocrine Unit, Massachusetts General Hospital, Harvard Medical School, Boston, MA. Blauwet is with the Dept. of Physical Medicine and Rehabilitation, Harvard Medical School, Spaulding Rehabilitation Hospital/Brigham and Women's Hospital, Boston, MA. Constantini is with the Heidi Rothberg Sport Medicine Center, Shaare Zedek Medical Center, Hebrew University, Jerusalem, Israel. Lebrun is with the Dept. of Family Medicine, Faculty of Medicine \& Dentistry, Glen Sather Sports Medicine Clinic, University of Alberta, Edmonton, Alberta, Canada. Melin is with the Dept. of Nutrition, Exercise and Sport, University of Copenhagen, Frederiksberg, Denmark. Meyer is with the Health Sciences Dept., University of Colorado, Colorado Springs, CO. Sherman is with Bloomington, Indiana, IN. Tenforde is with the Dept. of Physical Medicine and Rehabilitation, Harvard Medical School, Spaulding Rehabilitation Hospital, Charlestown, MA. Torstveit is with the Faculty of Health and Sport Sciences, University of Agder, Kristiansand, Norway. Budgett is with the IOC Medical and Scientific Dept., Lausanne, Switzerland. Address author correspondence to Margo Mountjoy at mmsportdoc@mcmaster.ca.
} 


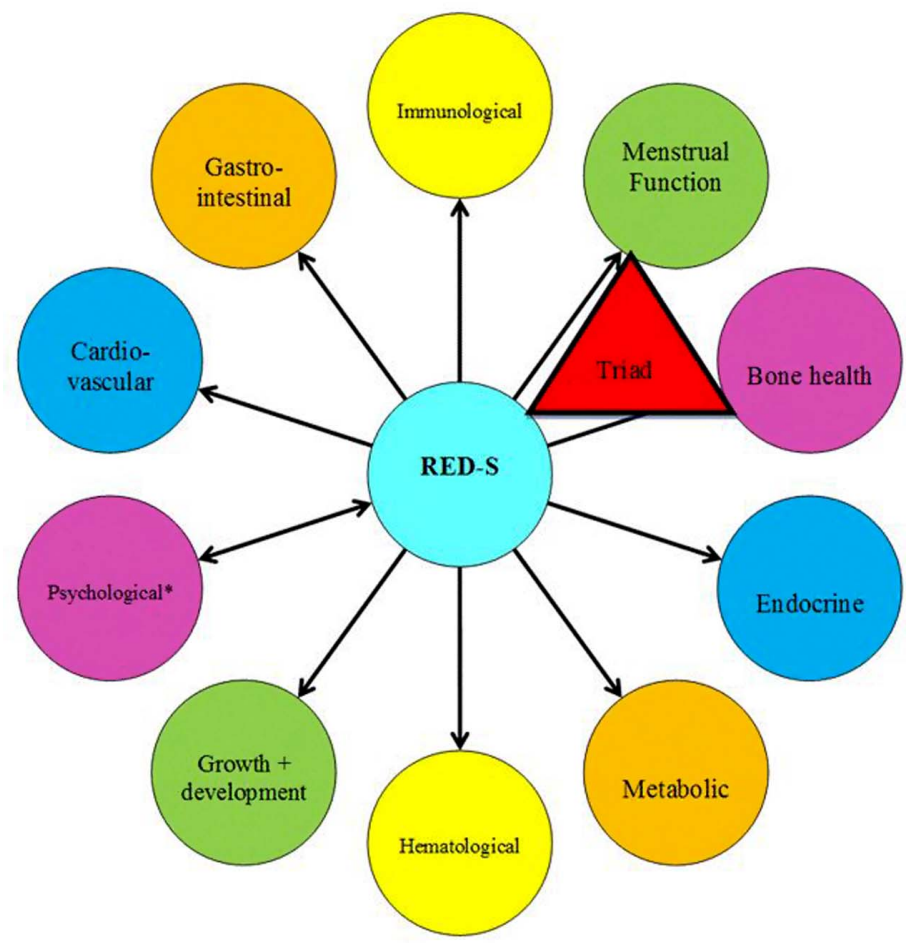

Figure 1 - Health Consequence of Relative Energy Deficiency in Sport (RED-S) showing an expanded concept of the Female Athlete Triad to acknowledge a wider range of outcomes and the application to male athletes (*Psychological consequences can either precede RED-S or be the results of RED-S).

\section{Relative energy deficiency in male athletes}

3. The measurement of LEA

4. The performance parameters identified in the RED-S conceptual model (Figure 2) (Constantini, 2002; Mountjoy et al., 2014)

The IOC RED-S consensus authors have reconvened to provide an update summary of the interim scientific progress in the field of relative energy deficiency with the ultimate goal of stimulating advances in RED-S awareness, clinical application, and scientific research to address current gaps in knowledge.

\section{Low Energy Availability}

LEA, which underpins the concept of RED-S, is a mismatch between an athlete's energy intake (diet) and the energy expended in exercise, leaving inadequate energy to support the functions required by the body to maintain optimal health and performance. Operationally, energy availability (EA) is defined as:

$$
\begin{aligned}
& \text { Energy Availability (EA) }=[\text { Energy intake }(\mathrm{EI})(\mathrm{kcal}) \\
& \text { - Exercise Energy Expenditure (EEE) (kcal) }] \\
& \text { /Fat-free mass }(\mathrm{FFM})(\mathrm{kg})
\end{aligned}
$$

where exercise energy expenditure is calculated as the additional energy expended above that of daily living during the exercise bout, and the overall result is expressed relative to FFM, reflecting the body's most metabolically active tissues (Loucks et al., 2011; Melin \& Lundy, 2015). Rigorously controlled laboratory trials in

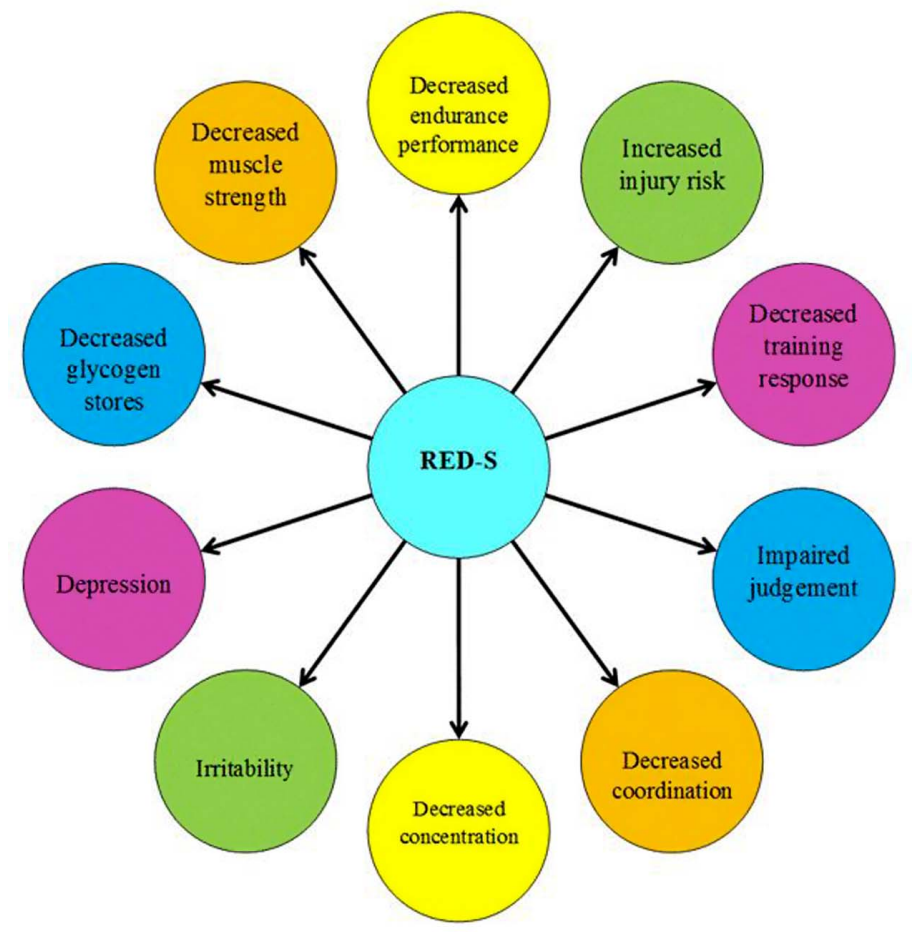

Figure 2 - Potential Performance Effects of Relative Energy Deficiency in Sport (RED-S) (*Aerobic and anaerobic performance) Adapted from Constantini.

women have shown that optimal EA for healthy physiological function is typically achieved at an EA of $45 \mathrm{kcal} / \mathrm{kg}$ FFM/day (188 kJ/kg FFM/day) (Loucks \& Heath, 1994; Loucks \& Thuma, 2003). Meanwhile, although some caveats are noted in relation to differential responses of various body systems (Burke \& Deakin, 2015), many of these systems are substantially perturbed at an $\mathrm{EA}<30 \mathrm{kcal} / \mathrm{kg}$ FFM/day (125 kJ/kg FFM/day), making it historically a targeted threshold for LEA. However, recent evidence suggests that this cutoff does not predict amenorrhea in all women (Lieberman et al., 2018; Williams et al., 2015). In addition, and not withstanding differences across body sizes and pubertal age, it is noted that an EA of $30 \mathrm{kcal} / \mathrm{kg} / \mathrm{FFM}$ roughly equates to the average resting metabolic rate (RMR) (Loucks et al., 2011). Because LEA has proven robust in explaining markers of sub-optimal health and function in both laboratory (Loucks \& Heath, 1994; Loucks \& Thuma, 2003) and field settings (Melin et al., 2014; Vanheest et al., 2014), it seems logical that an EA assessment could serve as a diagnostic tool in the prevention or management of RED-S.

\section{Measurement of EA}

Despite the primary importance of determining whether an athlete has adequate EA, several barriers prohibit the direct measurement of EA from being a practical and reliable option. First, there is no standardised or reference protocol for undertaking an EA assessment (e.g., the number of collection days, methodologies for assessing energy intake, exercise energy expenditure, or FFM). Furthermore, there are significant concerns over the reliability and validity of each of these metrics. The greatest challenge is to gain an accurate record of usual energy intake from self-reported sources (Burke, Melin, et al., 2018; Burke \& Deakin, 2015). Other 
challenges include the measuring of exercise energy expenditure during many of the training/competition activities performed by athletes and accounting for their additional recreational/lifestyle activity (Burke \& Deakin, 2015; Cialdella-Kam et al., 2014). These problems may partially explain why many field studies report considerable discrepancies between EA calculations and symptoms associated with LEA (Aparicio-Ugarriza et al., 2015; Burke, Melin, et al., 2018; Burke \& Deakin, 2015; Levine, 2005; Pinheiro Volp et al., 2011). However, other explanations for these observations include: 1) the temporal dissociation between the period of mismatched eating and exercise behaviour that created the LEA problems and the occasion on which the EA assessment was undertaken; and 2) the interaction of other dietary characteristics that often co-exist with LEA and may exacerbate its effects (e.g., high intake of fibre, stimulants and artificial sweeteners; low energy density foods; high dietary restraint, poor spread of energy within a day) (Barron et al., 2016; Gaskins et al., 2009; Heikura et al., 2017; Melin et al., 2016; Reed et al., 2014). Even if these problems could be solved, EA calculations would likely involve specialised equipment and expertise (e.g., dual energy X-ray absorptiometry (DXA) measurement of body composition), good motivation and compliance of the athlete (e.g., keeping a food record or comprehensive activity diary), and considerable time and expertise to process the information. Additionally, LEA states may develop at different stages of training and competition due to varying physiological demands. An EA assessment may achieve some valuable outcomes, such as strengthening the interaction between the practitioner and athlete, which can create rapport, trust, and an appreciation of EA needs. However, the considerable effort needed to assess EA and its frailties as a stand-alone diagnostic tool prevent expert bodies from instituting it as a universally recommended measurement.

\section{Low Energy Availability in Male Athletes}

Similar to female athletes, there is growing evidence that males may experience LEA in situations when there is a mismatch between energy intake and the exercise energy expenditure of training or competition. Populations of male athletes at increased risk for LEA and resulting health consequences of RED-S include cyclists, rowers, runners, jockeys, and athletes in weight class combat sports (Barrack et al., 2017; Berkovich et al., 2016; Burke, Tenforde, et al., 2018; Fagerberg, 2017; Tenforde et al., 2016; Viner et al., 2015; Wilson et al., 2014). Factors that contribute to LEA in male athletes are varied and often unique to the sport. They include the cyclical changes in body mass and composition ("making weight"), prolonged inadequate energy intake to meet high exercise energy expenditure of endurance sport, punctuated changes in training volume/intensity, and participation in strenuous endurance events without accompanied changes in nutrition (Burke, Tenforde, et al., 2018). Inadequate food availability, including food insecurity from cultural practices or lack of financial resources may also contribute risk for LEA in some male athletes, even among high calibre athletes, as it undoubtedly also does in female athletes (Burke, Tenforde, et al., 2018).

While RED-S may occur in both sexes, there are likely differences in biological responses to LEA in male athletes compared to their female counterparts. The prevalence of LEA has been suggested to be higher in females than in males, although precise differences are unknown (Loucks, 2007). The threshold and duration of the LEA state required to induce RED-S in men is unknown. Reduction in the sex hormone testosterone is likely to be of greater health concern in male athletes (Hackney et al., 2005; Hooper et al., 2017; Tenforde et al., 2016).

\section{Low Energy Availability in Para Athletes}

The prevalence of LEA in para athletes is incompletely characterized (Blauwet et al., 2017). When extrapolating from trends noted in general populations of individuals with disability, it can be assumed that athletes who use a wheelchair for daily mobility are likely to have reduced baseline energy needs (Buchholz \& Pencharz, 2004; Price, 2010). Despite this, male and female athletes with spinal cord injury (SCI) may monitor or restrict body weight for sport and are at risk for nutrient deficiencies (Krempien \& Barr, 2011, 2012). Athletes with central neurologic injury, such as cerebral palsy, who demonstrate aberrant movement patterns that include dyskinesis or athetosis, may have higher energy expenditures than similar athletes without such nonpurposeful movements (Crosland \& Boyd, 2014). Additionally, the presence of central neurologic injury may result in alterations of the hypothalamic-pituitary axis and baseline menstrual function, regardless of energy status (Colantonio et al., 2010; Ranganathan et al., 2016; Ripley et al., 2008). Amputee athletes may have higher energy needs in the setting of prosthetic use and resultant gait asymmetry (Gonzalez et al., 1974).

Para athletes are at high risk for impaired bone health and bone-related injury secondary to many factors, including altered skeletal loading. For example, in unilateral amputees, the affected limb may exhibit reduced bone mineral density (BMD) (Sherk et al., 2008). Athletes with SCI have disuse osteopenia/osteoporosis affecting the lower extremities, however, positive adaptive changes in upper body BMD values have been reported in wheelchair basketball players compared to non-athletes (greater radial BMD, and trend towards increased lumbar BMD) (Goktepe et al., 2004). Characterizing effects of LEA on bone in para athletes requires consideration of baseline effects of each individual's underlying disability. More work is needed in this area.

Given rising participation in para sport from grassroots to elite levels, further research is needed to investigate the impact of LEA in athletes with a disability. The para athlete population requires screening for LEA to reduce complications of RED-S, including low BMD.

\section{Race and Low Energy Availability}

Whether race plays a role in the incidence and underlying aetiology of RED-S remains speculative. Research shows a lower risk of disordered eating (DE) in African-American, but not Latino female high-school athletes compared to Caucasians (Pernick et al., 2006; Rhea, 1999). It is currently unknown whether the prevalence of menstrual disorders differs among racially diverse athletic groups. Stress fractures in African-American military recruits are lower than in Caucasian recruits (Lappe et al., 2001). Meanwhile, male Kenyan runners have been observed to have greater BMD at weight-bearing sites (e.g., proximal femur) than healthy controls, but not at the lumbar spine, where Z-scores were reported to be below -2.0 in $40 \%$ of study subjects (Tam et al., 2018). Such runners may have LEA resulting from low energy intake and high exercise energy expenditure associated with heavy training loads (Tam et al., 2018), as has been previously shown (Mukeshi \& Thairu, 1993; Onywera et al., 2004). In another study of young Kenyan female athletes, middle- and long-distance runners were found to exhibit one or more subclinical and/or clinical components 
of the RED-S, including a greater risk for LEA and menstrual dysfunction than controls (Muia et al., 2016). A study of sport nutrition knowledge, behaviors, and beliefs across sex, race/ ethnicity, and socioeconomic status in high school soccer players identified that general sports nutrition knowledge is lower in adolescent soccer players compared to prior reports in adolescent athletes, and that specifically females and Latinos may benefit from sport nutrition education (Manore et al., 2017). Published research is greatly lacking on RED-S in African American, Hispanic, and Asian athletes, with a few exceptions (Iwamoto et al., 2011; Quah et al., 2009). Thus, there is a need to include more diverse athlete populations in RED-S research and to integrate race/ethnicity in the prevention and treatment of RED-S.

\section{Health Effects of Low Energy Availability}

\section{Endocrine}

Effects of LEA on the endocrine system have been described predominantly in female athletes and only recently in male athletes. Findings in some female athletes in LEA states (measured EA and/or athletes with amenorrhea) include disruption of the hypothalamic-pituitary-gonadal axis, alterations in thyroid function, changes in appetite-regulating hormones (e.g., decreased leptin and oxytocin, increased ghrelin, peptide YY, and adiponectin), decreases in insulin and insulin-like growth factor 1 (IGF-1), increased growth hormone $(\mathrm{GH})$ resistance, and elevations in cortisol (Allaway et al., 2016; Ihle \& Loucks, 2004; Logue et al., 2018; Loucks \& Thuma, 2003; Misra, 2014). Many of these hormonal changes likely occur to conserve energy for more important bodily functions or to use the body's energy reserves for vital processes (Jasienska, 2003; Wade \& Jones, 2004).

Specific changes in men are not completely understood; however, reduced LH pulsatility and amplitude have been described in a case series of male marathon runners, a population at high risk for LEA (MacConnie et al., 1986). Other studies, primarily in endurance male athlete populations, have shown reductions in testosterone and inconsistent findings in differences in basal LH parameters (Hackney et al., 1988; McColl et al., 1989). Koehler et al. (2016) assessed the effects of short-term EA manipulation through diet and exercise on various hormonal parameters in 6 male habitual exercisers. Each male experienced 4 separate 4-day conditions: LEA (15 kcal/kg FFM/day with and without exercise) and adequate EA (40 kcal/kg FFM/day with and without exercise). Following both LEA conditions, regardless of exercise, leptin and insulin were reduced compared to baseline ( $-53 \%$ to $-56 \%$ and $-34 \%$ to $-38 \%$, respectively). LEA did not significantly affect ghrelin, triiodothyronine $\left(\mathrm{T}_{3}\right)$, testosterone, or IGF-1 levels. Thus, the LEA state, often in combination with disruptions to endocrine function in women and possibly men, may contribute to multiple physiological disease states described by RED-S. However, the relationship is likely to be subject to a large degree of within- and between-participant variability; more research is needed, particularly in men (Papageorgiou, Dolan, et al., 2018; Papageorgiou, Elliott-Sale, et al., 2017; Williams et al., 2015).

\section{Menstrual Function}

The effects of LEA on reproductive hormones and menstrual function in female athletes have been well-described (Gordon et al., 2017; Loucks \& Thuma, 2003; Nattiv et al., 2007), although the complex hormonal signaling pathways underpinning these effects are still being fully elucidated. Current evidence supports a LEA-associated disruption of Gonadotropin Releasing Hormone $(\mathrm{GnRH})$ pulsatility at the hypothalamus, followed by alterations of LH and FSH release from the pituitary and decreased estradiol and progesterone levels; this is considered a form of functional hypothalamic amenorrhea (FHA) (Curry et al., 2015; Gordon et al., 2017). The duration and severity of LEA needed to create such disturbances are also unclear, reflecting both the complex nature of the problem and discrepancies associated with the different methodologies used to study it. For example, Loucks and Thuma (2003) studied previously sedentary women in a laboratory setting and identified that well-controlled interventions reducing EA below $30 \mathrm{kcal} / \mathrm{kg}$ FFM/day via the short-term (5 day) manipulation of exercise energy expenditure and energy intake were associated with a dose-response decrease in LH pulsatility. More recently, Williams, et al. (2015) reduced EA via manipulation of energy intake and exercise energy expenditure over several menstrual cycles in untrained, previously eumenorrheic subjects. The researchers found that the frequency of menstrual disturbances (including luteal phase defects, anovulation, and oligomenorrhea) was affected by the magnitude of energy deficit compared to baseline needs (Williams et al., 2015), but a specific threshold of EA below which menstrual disturbances occurred was not identified (Lieberman et al., 2018).

Meanwhile, Reed et al. (2015) performed a cross-sectional analysis of EA (measured using 3-day diet logs to determine energy intake and a combination of exercise logs and heart rate monitoring to measure estimated exercise energy expenditure) in female athletes with eumenorrhea and various menstrual disturbances. These investigators reported mean EA was $>30.0 \mathrm{kcal} / \mathrm{kg}$ FFM/ day in all the groups (amenorrheic, oligomenorrheic, ovulatory eumenorrheic, inconsistent subclinical menstrual dysfunction eumenorrheic, and anovulatory eumenorrheic athletes) and EA did not discriminate subclinical forms of menstrual disturbance; however, EA was lower in amenorrheic athletes compared to eumenorrheic athletes (mean 30.9 vs. $36.9 \mathrm{kcal} / \mathrm{kg}$ FFM/day) (Reed et al., 2015). Thus, severe energy deficiency is known to lead to amenorrhea, but more work is needed to better understand the interplay of change in short and long-term EA and more subtle menstrual disruption.

\section{Bone Health}

It is established that LEA contributes to impaired bone health in athletes, particularly women. Cross-sectional studies of physically active female athletes with oligo-/amenorrhea or measured LEA have demonstrated decreased BMD, altered bone microarchitecture and bone turnover markers, decreased estimates of bone strength, and increased risk for bone stress injuries compared to eumenorrheic athletes and those who are energy replete (Ackerman et al., 2011, 2012; De Souza et al., 2008; Nattiv et al., 2007; Papageorgiou, Dolan, et al., 2018). Short-term LEA (via diet and exercise) has prospectively been shown to negatively affect bone turnover markers in women and some men (Ihle \& Loucks, 2004; Papageorgiou, Elliott-Sale, et al., 2017). Specific female and male sport populations are at increased risk for lower BMD, including jockeys, runners, swimmers, and cyclists (Andreoli \& Monteleone, 2001; Barrack et al., 2008, 2017; Fredericson et al., 2007; Hind et al., 2006; Morel et al., 2001; Nichols \& Rauh, 2011; Stewart \& Hannan, 2000; Tenforde et al., 2015; Viner et al., 2015; Wilson et al., 2014, 2015). Anatomical sites with less bone loading and/or greater trabecular versus cortical bone content (lumbar spine and 
radius vs. total hip) are at greater risk for low BMD and impaired microarchitecture in populations susceptible to LEA (Ackerman et al., 2011, 2012; Bilanin et al., 1989; Fredericson et al., 2007; Hind et al., 2006).

Low body mass index (BMI) is an imperfect surrogate marker for LEA. However, BMI $\leq 17.5 \mathrm{~kg} / \mathrm{m}^{2},<85 \%$ expected body weight for adolescents or $\geq 10 \%$ weight loss in one month are proposed indicators of LEA (De Souza, Nattiv, et al., 2014), and indeed both BMI and expected body weight cutoffs are associated with increased risk for low BMD in both sexes (Barrack et al., 2017; Tenforde et al., 2015; Thralls et al., 2016). LEA may be accompanied by DE/eating disorders (EDs), menstrual dysfunction, and low BMD, and the combination of factors places athletes at higher risk for bone stress injury (Ackerman et al., 2015; Barrack et al., 2014; Tenforde et al., 2017).

\section{Metabolic}

LEA has been correlated with decreased RMR in female endurance athletes (Melin et al., 2015). Prospectively, increasing training load while maintaining constant EI over 4 weeks in male and female elite rowers led to a significant reduction in RMR (Woods et al., 2017). In normal weight women with induced energy deficits via exercise and dietary manipulation, measured weight loss over 3 months was less than predicted (Koehler et al., 2017). Subjects who were moderately energy deficient had a significant decrease in RMR, and those who were severely energy deficient demonstrated significant decreases in leptin, $\mathrm{T}_{3}$, IGF-1, and an increase in ghrelin (Koehler et al., 2017).

\section{Hematological}

Iron is essential for hematopoiesis and subsequent oxygen carrying capacity. Iron deficiency, often seen in female athletes, can contribute directly and indirectly to energy deficiency. This is due to a potential reduction in appetite, decreased metabolic fuel availability, and impaired metabolic efficiency, leading to an increase in energy expenditure during exercise and rest (Petkus et al., 2017). Iron deficiency may also interact with bone health via dysregulation of the GH/IGF-1 axis, hypoxia, and hypothyroidism, in addition to playing an important role in thyroid function, fertility, and even psychological well-being (Petkus et al., 2017). Thus, LEA may be partially induced by, and may contribute to, iron deficiency (Petkus et al., 2017). Surrogates for LEA have been correlated with hematologic dysfunction, including low ferritin and iron deficiency anemia, in adolescent and young adult female athletes (Ackerman et al., 2018).

\section{Growth and Development}

Linear growth retardation has been reported in various studies of male and female adolescents with severe anorexia nervosa, with studies demonstrating partial, but not always complete, catch-up growth after recovery (Lantzouni et al., 2002; Modan-Moses et al., 2003, 2012). Decreases in IGF-1, increases in GH, and increased $\mathrm{GH}$ resistance are consistently noted in those with anorexia nervosa (Fazeli \& Klibanski, 2014). Studies in amenorrheic athletes have demonstrated disorderly $\mathrm{GH}$ secretory patterns, decreased GH and IGF-1 secretory response to exercise accompanied by increased interpulse GH levels, and decreased IGF-1/ IGFBP-1 ratios, with more research needed to understand training and growth implications (Laughlin \& Yen, 1996; Waters et al., 2001).
Cardiovascular. Early atherosclerosis may be associated with hypoestrogenism and FHA in young athletes (O'Donnell et al., 2011). Endothelial dysfunction and unfavorable lipid profiles have been reported in amenorrheic athletes (Rickenlund et al., 2005), with resumption of menses leading to improvements in vascular endothelial function (Hoch et al., 2007). In one study, amenorrheic athletes demonstrated lower heart rates and systolic blood pressure compared to eumenorrheic athletes, in addition to disruptions of the normal renin-angiotensin-aldosterone response to an orthostatic challenge (O'Donnell et al., 2015). In the more severe LEA state of anorexia nervosa, significant cardiovascular changes can occur, including valve abnormalities, pericardial effusion, severe bradycardia, hypotension, and arrhythmias (Spaulding-Barclay et al., 2016).

Gastrointestinal. In the severe LEA state of AN, negative health influences on the full gastrointestinal tract such as altered sphincter function, delayed gastric emptying, constipation, and increased intestinal transit time, have been described (Norris et al., 2016). Melin et al. (2014) measured EA and developed the Low Energy Availability among Female Athletes Questionnaire (LEAF-Q), both of which found a negative correlation with EA and gastrointestinal symptoms in elite Swedish and Danish athletes. These findings were supported in a survey of adolescent American female athletes with surrogate markers of LEA, who also reported a higher incidence of stool leakage and constipation than those considered to have adequate EA (Ackerman et al., 2018).

Immunological. The immune system may be altered by LEA. A study of 21 Japanese elite, collegiate runners reported more upper respiratory symptoms and lower immunoglobulin A secretion rates in the amenorrheic versus eumenorrheic athletes (Shimizu et al., 2012). Meanwhile, in observational studies of elite Australian athletes in preparation for the 2016 Rio Olympic Games, LEA, as measured by the LEAF-Q in female athletes, was associated with increased likelihood of illnesses (including those of the upper respiratory tract and gastrointestinal tract), bodily aches, and head-related symptoms in the previous month (Drew et al., 2017, 2018).

Psychological. Psychological problems can precede or be caused by LEA (Mountjoy et al., 2014). LEA in athletes has been shown to have negative correlates with various aspects of psychological well-being. Higher drive for thinness may be a proxy for LEA, as higher drive for thinness scores on the Eating Disorder Inventory have been associated with reduced resting energy expenditure, lower $\mathrm{T}_{3}$ levels, and higher ghrelin levels in female athletes (De Souza et al., 2007). Athletes who scored higher on DT also scored higher in domains of ineffectiveness, cognitive restraint, and bulimic tendencies (De Souza et al., 2007). Adolescent females with FHA have been found to have a higher incidence of mild depressive traits, psychosomatic disorders, and a decreased ability to manage stress (Bomba et al., 2007; Marcus et al., 2001). A separate study found overlap in adolescents with anorexia nervosa and those with FHA: both groups demonstrated increased depression, social insecurity and introversion, and fears of weight gain compared to healthy controls (Bomba et al., 2014). More profound psychological disturbances were seen in the presumably more restricted EA (anorexia nervosa) group versus the FHA group (Bomba et al., 2014). Results from a study with male athletes indicated that dietary restraint and muscle building behaviors were associated with bulimic symptomatology (Petrie et al., 2014). Additionally, studies of male body builders indicate that a prolonged EA of approximately $20-25 \mathrm{kcal} / \mathrm{kg}$ FFM/day, as seen in 
the final stage of contest diets, might be pathological and have negative psychological effects for males (Fagerberg, 2017). The restrictive diet patterns observed resulted in a reduction in muscle mass and a loss of strength, with reports of endocrine dysfunction and mood disturbances in those athletes with body composition measurements of approximately $4 \%$ total body fat (Fagerberg, 2017).

\section{Disordered Eating and Eating Disorders}

Disordered eating and eating disorders are more prevalent among female and male athletes in weight-sensitive sports in comparison to athletes representing sports in which leanness is a less important performance variable (Kong \& Harris, 2015; Sundgot-Borgen, 1993; Sundgot-Borgen \& Torstveit, 2004; Sykora et al., 1993; Thiemann et al., 2015). In a Norwegian study of adolescent elite male and female athletes, a higher prevalence of disordered eating in non-athletes as compared to athletes was found when using questionnaires (Martinsen et al., 2010), but when using a clinical interview, the prevalence of eating disorders was higher in athletes versus controls (Martinsen \& Sundgot-Borgen, 2013). These findings suggest the need for personal interviews to diagnose eating disorders in athletes (Fairburn et al., 2008; Martinsen \& SundgotBorgen, 2013; Sundgot-Borgen \& Torstveit, 2004). It should be noted that the revised diagnostic criteria for eating disorders (Diagnostic and Statistical Manual, 5th edition) may influence the prevalence of the different diagnoses among athletes (American Psychiatric Association, 2013; Vo et al., 2017).

The pathogenesis of eating disorders is multifactorial with cultural, familial, individual, and genetic/biochemical factors playing roles (Stice et al., 2012). Weight pressure and unique eating disorder risk and trigger factors have been reported and include performance pressure, sudden increase in training volume, injury, teammate modeling of eating disorder behaviors, and team weighins (Arthur-Cameselle et al., 2017; Krentz \& Warschburger, 2013; Sundgot-Borgen, 1994). A desire to be leaner to enhance performance seems to predict later disordered eating (Krentz \& Warschburger, 2013), and the risk of eating pathology increases when the coach-athlete relationship is characterized by high conflict and low support (Shanmugam et al., 2014). Disordered eating seems to be influenced by perfectionism, competitiveness, pain tolerance, and the perceived performance advantage of weight loss (Stirling \& Kerr, 2012). These suggested risk factors need to be validated to demonstrate a causal relationship. However, these findings serve as a call to action for enhanced screening for eating disorder risk among athletes who experience weight pressure, are injured, or who have teammates with known disordered eating/ eating disorders (Arthur-Cameselle et al., 2017).

\section{Performance Consequences of Low Energy Availability}

Associations between various surrogates of LEA (e.g., hormonal aberrations, oligo-/amenorrhea, leanness sport participation, and increased scores on ED/DE/LEA screening tools) and factors negatively influencing performance (e.g., illness, injury, iron deficiency, impaired cognition and mood) have been reported (Ackerman et al., 2015, 2018; Baskaran et al., 2017; Burden et al., 2015; Geesmann et al., 2017; Hagmar et al., 2013; Harber et al., 1998; Petkus et al., 2017; Rauh et al., 2010; Thein-Nissenbaum et al., 2014). Intervention studies on long-term energy restriction and sport performance are lacking (El Ghoch et al., 2013).
However, it has been postulated that persistent LEA could impair sport performance through a variety of different indirect mechanisms (e.g., impaired recovery leading to premature reduction in physical, psychological, and mental capacity and impairment of optimal muscle mass and function) (Fogelholm, 1994). Indeed, LEA could be expected to impair performance or interfere with optimal performance gains via acute impairment of key processes such as glycogen storage (Tarnopolsky et al., 2001) or protein synthesis (Areta et al., 2014), or by preventing consistent and high quality training due to the increased risk of injury and illness (Drew et al., 2017, 2018).

Despite the importance of these associations, it is only recently that studies have tried to measure the direct impact of LEA on sports performance. For example, Silva and Paiva (2016) reported that athletic performance, measured as competition ranking, negatively correlated with EA in elite rhythmic gymnasts. Furthermore, Tornberg et al. (2017) found no difference in aerobic capacity $\left[\mathrm{VO}_{2}, \mathrm{O}_{2}(\mathrm{~mL} / \mathrm{min} / \mathrm{kg})\right]$ between elite eumenorrheic endurance athletes and elite endurance athletes with secondary FHA, despite lower body weight and fat mass in the athletes with FHA. However, subjects with FHA had decreased neuromuscular performance (measured as knee muscular strength and endurance) and reaction time compared with the eumenorrheic athletes (Tornberg et al., 2017). Overall, lower neuromuscular performance was associated with higher cortisol levels, and lower blood glucose, $\mathrm{T}_{3}$, estrogen, and FFM in the tested leg (Tornberg et al., 2017). Although striving for a greater power to mass ratio is commonly regarded as important for running performance, this study suggests that achieving an idealized body weight or body composition through severe and persistent energy restriction is likely to negatively affect performance and health (Tornberg et al., 2017). This finding is supported in a study of East African runners (Mooses \& Hackney, 2017). Woods et al. (2017) followed male and female national team rowers through a 4 week intensified training period, which was accompanied by a lack of increase in energy intake despite a $21 \%$ increase in training load. It was concluded that inadequate EA likely negatively affected training recovery, at least partially explaining the alterations in $5 \mathrm{~km}$ time trial pacing strategy and reduced performance (Woods et al., 2017).

Considering the reported high prevalence of menstrual dysfunction caused by energy deficiency (Gibbs et al., 2013), surprisingly, only one study has investigated the direct impact of LEA on sport performance. Vanheest et al. (2014) reported a $10 \%$ decline in swimming velocity over a $400 \mathrm{~m}$ time trial (after 12 weeks of training) among young elite swimmers with ovarian suppression secondary to energy deficiency compared to an $8 \%$ improvement in their eumenorrheic teammates. Clearly, more investigations, including robust protocols involving random allocation of athletes to intervention groups, are needed to provide further evidence and explanation of the effects of LEA on training adaptations and sport performance.

\section{Prevention of Relative Energy Deficiency in Sport}

The prevention of RED-S requires increased awareness among athletes and their entourage. Current evidence suggests that there is much work to be done. Surveys have reported that less than 50\% of physicians, coaches, physiotherapists and athletic trainers could identify the Triad components (LEA with or without an eating disorder, menstrual dysfunction, and low BMD) (Brown et al., 
2014; Curry et al., 2015; Feldmann et al., 2011; Kroshus et al., 2014; Mukherjee et al., 2016; Pantano, 2006, 2017; Troy et al., 2006), and only $19 \%$ of 370 U.S. high school nurses could identify all three Triad components (Kroshus et al., 2015). In a survey of 931 multi-specialty physicians, only $37 \%$ were aware of the Triad, and only one half of these were comfortable treating or referring a patient (Curry et al., 2015). In a group of exercising Australian women, one third believed irregular periods were "normal" for active females, and approximately half reported knowing that menstrual dysfunction was a risk factor for poor bone health (Miller et al., 2012). Educational programs typically identify their target audiences as health professionals, coaches, athletic trainers, teachers, school administrators, athletes, and parents (TorresMcGehee et al., 2012). However, a survey of International Sport Federations (IFs) identified that only 2 of 28 Olympic IFs had programmes on RED-S, indicating the need to also involve a topdown approach (Mountjoy et al., 2018). Peer-based eating disorder/body image/Triad education and cognitive-dissonance based programs have shown promise (Brown et al., 2016; Kilpela et al., 2016; Temme et al., 2013; Valliant et al., 2012), and similar RED-S peer-led programs should be developed.

Effective eating disorder prevention programs should be multi-modal, interactive, and target athletes and coaching staff (Bar et al., 2016). One successful intervention is a peer-led educational program for female athletes that resulted in improved bulimic pathology one-year post intervention (Becker et al., 2012). A Norwegian school-based controlled intervention program, including elite male and female athletes (Martinsen et al., 2014) and coaches (Martinsen et al., 2015), resulted in no new cases of eating disorders among females in the intervention schools as opposed to $8(13 \%)$ in females at the control schools (Martinsen et al., 2014). There was only one new eating disorder case in a male at a control school and none in males from the intervention schools (Martinsen et al., 2014). These results suggest that effective disordered eating and eating disorder prevention should target individuals beyond athletes and coaches, be gender specific, involve significant others, and include changes to sport regulations, policy measures. and the health care system (de Bruin, 2017).

\section{Screening for Relative Energy Deficiency in Sport}

Early detection of athletes at risk for energy deficiency is critical to prevent long-term health sequelae (De Souza, Nattiv, et al., 2014; Mountjoy et al., 2014; Nattiv et al., 2007). There are several disordered eating/eating disorder screening tools intended for general population (Fairburn \& Beglin, 1994; Garner et al., 1983; Garner \& Garfinkel, 1979; Hill et al., 2010). Some tools have been developed to target athletes, although none are validated for DSM-5 criteria (Hinton \& Kubas, 2005; McNulty et al., 2001; Steiner et al., 2003). Additionally, due to stigma associated with eating disorders, athletes may be motivated to hide their illness. An elevated Eating Disorder Inventory - drive for thinness score (Garner et al., 1983) has been reported to indicate energy deficiency in exercising women (Gibbs et al., 2011), and amenorrheic athletes seem more likely to have an elevated drive for thinness score compared to eumenorrheic athletes (Gibbs et al., 2011). In order to diagnose an eating disorder, additional in-depth personal interviews must be performed (Fairburn et al., 2008; Fairburn \& Beglin, 1994; Martinsen \& Sundgot-Borgen, 2013; Sundgot-Borgen \& Torstveit, 2004). However, the prevalence of energy deficiency is reported to be high in some athletes even without the presence of disordered eating/eating disorders (Gibbs et al., 2013; Melin et al., 2015).

Although coaches are in an ideal situation to identify athletes with disordered eating/eating disorders, they sometimes have difficulty distinguishing between athletes whose appearance or body composition metrics meets their sport-type expectations (e.g., thin) from those with an eating disorder, especially if the athlete's performance is good (Plateau et al., 2013). Even if disordered eating is identified, coaches may have difficulty convincing athletes to seek treatment (Plateau et al., 2017).

The Periodic Health Examination (Ljungqvist et al., 2009) and the Preparticipation Physical Evaluation (American Academy of Family Physicians et al., 2010) include relevant questions that may be helpful for early detection. Recently, the LEAF-Q was developed (Melin et al., 2014) as a brief questionnaire on physiological symptoms linked to energy deficiency, and the Low Energy Availability in Males Questionnaire (LEAM-Q) is in development. Expanded testing of these questionnaires in various athletic populations is needed. There is limited evidence for the efficacy of self-reported questionnaires, and additional individual evaluation is recommended (De Souza, Nattiv, et al., 2014; Mountjoy et al., 2014). The RED-S Clinical Assessment Tool (RED-S CAT) can assist clinicians in screening for RED-S and the management of return to play decisions (Mountjoy, Sundgot-Borgen, Burke, Carter, Constantini, Lebrun, Meyer, Sherman, Steffen, Budgett, Ljungqvist, et al., 2015), although validation is needed.

\section{Treatment of Relative Energy Deficiency in Sport}

\section{Non-pharmacologic Management}

If LEA is due to unintentional undereating, then simple nutritional education may suffice. Regardless of the severity of the eating pathology, early involvement of an accredited or appropriately trained expert (e.g., sports dietitian) is recommended to enhance the athlete's nutritional practices. Optimizing EA can improve function of the hypothalamic-pituitary-gonadal axis, as well as other systems negatively affected by LEA in females (Cialdella-Kam et al., 2014; Dueck et al., 1996; Kopp-Woodroffe et al., 1999; Mallinson et al., 2013). Energy deficits should be addressed via modification of exercise and nutrition practices in both female and male athletes, and energy needs may be even higher in growing adolescents (Bhasin et al., 2010; Gordon et al., 2017). Treatment is typically based on increased food intake but may also require changes in food choices, energy spread, and other dietary characteristics; these changes must be individualized and periodized according to the athlete's energy expenditure and exercise goals. A reduction or cessation of exercise may be necessary, depending on the severity of the energy deficit, symptoms, and compliance level.

Adequate bone-building nutrients are critical; for example, serum 25-hydroxy vitamin D levels $<30 \mathrm{ng} / \mathrm{mL}$ are associated with increased incidence of bone stress injury (Moreira \& Bilezikian, 2017; Ruohola et al., 2006). Vitamin D intake of 600-800 IU daily is recommended by USDA dietary guidelines (U.S. Department of Agriculture, 2011), but greater intake may be needed temporarily to reach goal serum 25-hydroxy vitamin D levels of $>30 \mathrm{ng} / \mathrm{mL}$ (Golden \& Carey, 2016; Holick et al., 2011; Sacheck et al., 2017). Improving 25-hydroxy vitamin D levels may also reduce healing time and facilitate earlier return to play for bone stress injury (Kim et al., 2016). Additionally, adequate consumption of calcium may 
help decrease the incidence of bone stress injury (Myburgh et al., 1990; Nieves et al., 2010). The current recommendation for daily calcium intake is $1000 \mathrm{mg} / \mathrm{day}$ of calcium for men and women ages $19-50$ years, and $1300 \mathrm{mg} / \mathrm{day}$ for children and adolescents ages 9-18 years (US Department of Health and Human Services, 2015).

Cognitive behavioral therapy is another non-pharmacological treatment for RED-S that has been shown to contribute to the resumption of menses in some women with FHA (Berga \& Loucks, 2006; Michopoulos et al., 2013). Initial non-pharmacologic management of RED-S may restore menstrual function over months (Arends et al., 2012; Mallinson et al., 2013) while improvements in bone health take longer and may never reach optimal levels (Cialdella-Kam et al., 2014). Non-compliance with therapy may require removal of the athlete from training/competition. Examples of treatment contracts and clearance categories for return to play can be found in other publications (De Souza, Nattiv, et al., 2014; Joy et al., 2016; Mountjoy et al., 2014). Current recommendations need further validation and may lead to the eventual inclusion of other progress parameters, such as RMR and blood biomarkers.

\section{Pharmacologic Interventions}

The use of combined oral contraceptives for the intention of regaining menses or improving BMD in those with RED-S is not recommended. Data regarding the effects of combined oral contraceptives on BMD and fracture risk are inconsistent (Cobb et al., 2007; Ducher et al., 2011; Gordon et al., 2017; Lopez et al., 2014, 2015). If using combined oral contraceptives for contraception, the athlete should understand that combined oral contraceptives may mask the return of spontaneous menses and bone loss may continue if the energy deficit is not corrected. If menstrual cycles do not return after a reasonable trial of nutritional, psychological and/or modified exercise interventions, transdermal estradiol (E2) therapy with cyclic oral progestin can be considered for short-term use (Gordon et al., 2017). Notably transdermal E2 is not a reliable form of hormonal contraception and an athlete should be counseled to avoid unintended pregnancy if she receives transdermal E2 for bone health. Transdermal estrogen does not affect IGF-1 secretion, a bone-trophic hormone that combined oral contraceptives downregulate, and has been shown to improve BMD in anorexia nervosa (Misra et al., 2011) and BMD and bone microarchitecture in oligo-amenorrheic athletes (Ackerman et al., 2017). Recombinant parathyroid hormone 1-34 (rPTH) has been shown to improve BMD in AN (Fazeli et al., 2014) and rare, short-term use may be considered in adults with LEA, FHA, or RED-S in the setting of delayed fracture healing or very low BMD (Gordon et al., 2017). Transdermal estrogen or $\mathrm{PPTH}$ should only be prescribed in conjunction with a metabolic bone expert and it is important to note that $\mathrm{rPTH}$ is contraindicated in adolescents and young adults with open growth plates (Gordon et al., 2017).

\section{Treatment Strategies for Disordered Eating/Eating Disorders}

Apparent disordered eating/eating disorders should be treated with a multidisciplinary team including medical, dietary, and mental health support. Inpatient treatment should be considered for patients with severe bradycardia, hypotension, orthostasis, and/or electrolyte imbalance (De Souza, Nattiv, et al., 2014; Joy et al., 2016; Temme \& Hoch, 2013). Athletes' resistance to treatment usually increases with the severity of the problem
(Thompson \& Sherman, 2011). Because many patients with eating disorders see their disorders as purposeful and necessary (Clausen et al., 2013), motivation to recover is a critical factor in treatment. With sport participation as leverage for athletes, the desire to be healthy enough to return to sport most often facilitates recovery for athletes with eating disorders (Arthur-Cameselle \& Quatromoni, 2014).

As higher levels of depression and anxiety are observed in athletes with eating pathology (Giel et al., 2016), there is a need to treat these pathologies in athletes with disordered eating/eating disorders. Additionally, comorbid disorders of depression, anxiety, and substance abuse complicate eating disorder treatment and require treatment modifications (de Bruin, 2017; Sansone \& Sansone, 2007). Ideally, treatment should be provided by a mental health professional experienced in treating eating problems in athletes (Thompson \& Sherman, 2011). For athletes meeting the diagnostic criteria for severe eating disorders (e.g., anorexia nervosa and bulimia nervosa), participation in competition is not recommended (Mountjoy et al., 2014).

\section{Conclusions}

Since the original publication of the IOC consensus statement on RED-S in 2014, there have been many scientific advances to improve our understanding of the health and performance effects of LEA in both female and male athletes. To address remaining gaps, the IOC RED-S consensus authors encourage scientific activity in the following domains:

1. Identification of athletes at risk for RED-S: It is evident that there is no practical tool for the measurement of EA, therefore, there is a recognized need to develop a methodology to screen and identify athletes at risk for RED-S that is both scientifically validated as well as relevant and applicable in clinical sport practice.

2. Prevention of RED-S: Improved awareness of RED-S is required through educational initiatives for athletes, coaches, members of the entourage, and sport organizations. The development of scientifically validated prevention interventions is encouraged.

3. Male athletes: Despite the improvement in the knowledge base of RED-S in male athletes, there remains a gap in our understanding of RED-S in specific sports with differing energy demands, performance criteria, ethnicities and cultural perspectives.

4. Health and performance consequences of RED-S: There is still much to be learned about the psychological and physiological health risks and long-term consequences of RED-S in all athletes, particularly male athletes, para athletes, and athletes of various races. To best engage the attention of athletes and coaches, it is imperative to further increase our understanding of the performance effects of RED-S.

5. Treatment and 'return to play': Practical guidelines for the treatment and safe return to play for athletes with RED-S need to be further developed to improve athletes' health and performance.

\section{Note}

The Corresponding Author has the right to grant on behalf of all authors and does grant on behalf of all authors, an exclusive licence (or non 
exclusive for government employees) on a worldwide basis to the BMJ Publishing Group Ltd and its Licensees to permit this article (if accepted) to be published in Journal (British Journal of Sports Medicine) editions and any other BMJPGL products to exploit all subsidiary rights, as set out in our licence (http://bjsm.bmjjournals.com/misc/ifora/licenceform.shtml). This work was not funded by an external source. The authors have no conflicts of interest to disclose.This article has been co-published in the British Journal of Sports Medicine; doi: 10.1136/bjsports-2018-099193.

\section{Acknowledgments}

The authors would like to gratefully acknowledge the work of Barbara Drinkwater in the field of the Female Athlete Triad, and for her ongoing support of the advancement of science in this domain. A special thank you to Allyson L. Parziale and Bryan Holtzman for their logistical and editorial assistance.

\section{Scientific Contributions of Each Author}

Margo Mountjoy MD, PhD: First author, substantial contributions to conception and design, co-coordinator of IOC Expert Group, drafting and revising the manuscript and confirmation of final version to be published.

Jorunn Sundgot-Borgen PhD: Second author, substantial contributions to conception and design, co-coordinator of IOC Expert Group, drafting and revising the manuscript and confirmation of final version to be published.

Louise Burke PhD: Third author, substantial contributions to conception and design, co-coordinator of IOC Expert Group, drafting and revising the manuscript and confirmation of final version to be published.

Kathryn E. Ackerman MD, MPH: Fourth author, substantial contributions to drafting and revising the manuscript and confirmation of final version to be published.

Cheri Blauwet MD, Naama Constantini MD, Constance Lebrun MD, Bronwen Lundy MND, Anna Melin PhD, Nanna Meyer PhD, Roberta Sherman PhD, Adam Tenforde MD, Monica K. Torstveit PhD: Members of IOC Expert Group, substantial contribution to drafting and confirmation of final revision of the manuscript to be published.

Richard Budgett MD: Director IOC Medical \& Scientific Department, revising the manuscript and confirmation of final version to be published.

\section{References}

Ackerman, K.E., Holtzman, B., Cooper, K.M., Flynn, E.F., Bruinvels, G., Tenforde, A.S., ... Parziale, A.L. (2018). Low energy availability surrogates correlate with health and performance consequences of relative energy deficiency in sport (red-s). British Journal of Sports Medicine. In Press.

Ackerman, K.E., Nazem, T., Chapko, D., Russell, M., Mendes, N., Taylor, A.P., ... Misra, M. (2011). Bone microarchitecture is impaired in adolescent amenorrheic athletes compared with eumenorrheic athletes and nonathletic controls. Journal of Clinical Endocrinology and Metabolism, 96(10), 3123-3133. PubMed ID: 21816790 doi: 10.1210/jc.2011-1614

Ackerman, K.E., Putman, M., Guereca, G., Taylor, A.P., Pierce, L., Herzog, D.B., ... Misra, M. (2012). Cortical microstructure and estimated bone strength in young amenorrheic athletes, eumenorrheic athletes and non-athletes. Bone, 51(4), 680-687. PubMed ID: 22878154 doi:10.1016/j.bone.2012.07.019

Ackerman, K.E., Singhal, V., Baskaran, C., Slattery, M., Campoverde Reyes, K., Toth, A., ... Misra, M. (2017). Transdermal 17- $\beta$ estradiol has a beneficial effect on bone parameters assessed using hrpqct compared to oral ethinyl estradiol-progesterone combination pills in oligo-amenorrheic athletes: A randomized controlled trial. In American society for bone and mineral research. Denver, CO.

Ackerman, K.E., Sokoloff, N.C., De Nardo Maffazioli, G., Clarke, H.M., Lee, H., \& Misra, M. (2015). Fractures in relation to menstrual status and bone parameters in young athletes. Medicine \& Science in Sports \& Exercise, 47(8), 1577-1586. PubMed ID: 25397605 doi:10.1249/ MSS.0000000000000574

Allaway, H.C.M., Southmayd, E.A., \& De Souza, M.J. (2016). The physiology of functional hypothalamic amenorrhea associated with energy deficiency in exercising women and in women with anorexia nervosa. Hormone Molecular Biology and Clinical Investigation, 25(2), 91-119. PubMed ID: 26953710 doi:10.1515/hmbci-2015-0053

American Academy of Family Physicians, American Academy of Pediatrics, American College of Sports Medicine, \& American Medical Society for Sports Medicine. (2010). Preparticipation physical evaluation. In D.T. Berhardt, \& W.O. Roberts (Eds.), (4th ed.).

American Psychiatric Association. (2013). Diagnostic and statistical manual of mental disorders: DSM-5. American Psychiatric Association. doi:10.1176/appi.books.9780890425596.744053

Andreoli, A., \& Monteleone, M. (2001). Effects of different sports on bone density and muscle mass in highly trained athletes. Medicine \& Science in Sports \& Exercise, 33, 507-511. PubMed ID: 11283423

Aparicio-Ugarriza, R., Mielgo-Ayuso, J., Benito, P.J., Pedrero-Chamizo, R., Ara, I., Gonzalez-Gross, M., \& Group, E.S. (2015). Physical activity assessment in the general population; instrumental methods and new technologies. Nutricion Hospitalaria, 31(Suppl. 3), 219 226. doi:10.3305/nh.2015.31.sup3.8769

Arends, J.C., Cheung, M.Y.C., Barrack, M.T., \& Nattiv, A. (2012). Restoration of menses with nonpharmacologic therapy in college athletes with menstrual disturbances: A 5-year retrospective study. International Journal of Sport Nutrition and Exercise Metabolism, 22(2), 98-108. PubMed ID: 22465870 doi:10.1123/ijsnem. 22.2 .98

Areta, J.L., Burke, L.M., Camera, D.M., West, D.W., Crawshay, S., Moore, D.R., ... Coffey, V.G. (2014). Reduced resting skeletal muscle protein synthesis is rescued by resistance exercise and protein ingestion following short-term energy deficit. AJP: Endocrinology and Metabolism, 306(8), E989-E997. doi:10.1152/ajpendo.00590. 2013

Arthur-Cameselle, J.N., \& Quatromoni, P.A. (2014). Eating disorders in collegiate female athletes: Factors that assist recovery. Eating Disorders, 22(1), 50-61. PubMed ID: 24365527 doi:10.1080/10640266 .2014 .857518

Arthur-Cameselle, J.N., Sossin, K., \& Quatromoni, P.A. (2017). A qualitative analysis of factors related to eating disorder onset in female collegiate athletes and non-athletes. Eating Disorders, 25(3), 199-215. PubMed ID: 27897463 doi:10.1080/10640266. 2016.1258940

Bar, R.J., Cassin, S.E., \& Dionne, M.M. (2016). Eating disorder prevention initiatives for athletes: A review. European Journal of Sport Science, 16(3), 325-335. PubMed ID: 25815432 doi:10.1080/ 17461391.2015.1013995

Barrack, M.T., Fredericson, M., Tenforde, A.S., \& Nattiv, A. (2017). Evidence of a cumulative effect for risk factors predicting low bone mass among male adolescent athletes. British Journal of Sports 
Medicine, 51(3), 200-205. Retrieved from http://bjsm.bmj.com/ content/51/3/200.abstract

Barrack, M.T., Gibbs, J.C., De Souza, M.J., Williams, N.I., Nichols, J.F., Rauh, M.J., \& Nattiv, A. (2014). Higher incidence of bone stress injuries with increasing female athlete triad-related risk factors: A prospective multisite study of exercising girls and women. American Journal of Sports Medicine, 42(4), 949-958. PubMed ID: 24567250 doi:10.1177/0363546513520295

Barrack, M.T., Rauh, M.J., \& Nichols, J.F. (2008). Prevalence of and traits associated with low BMD among female adolescent runners. Medicine \& Science in Sports \& Exercise, 40(12), 2015-2021. PubMed ID: 18981950 doi:10.1249/MSS.0b013e3181822ea0

Barron, E., Sokoloff, N.C., Maffazioli, G.D.N., Ackerman, K.E., Woolley, R., Holmes, T.M., ... Misra, M. (2016). Diets high in fiber and vegetable protein are associated with low lumbar bone mineral density in young athletes with oligoamenorrhea. Journal of the Academy of Nutrition and Dietetics, 116(3), 481-489. PubMed ID: 26686817 doi:10.1016/j.jand.2015.10.022

Baskaran, C., Plessow, F., Ackerman, K.E., Singhal, V., Eddy, K.T., \& Misra, M. (2017). A cross-sectional analysis of verbal memory and executive control across athletes with varying menstrual status and non-athletes. Psychiatry Research, 258, 605-606. PubMed ID: 28159335 doi:10.1016/j.psychres.2016.12.054

Becker, C.B., McDaniel, L., Bull, S., Powell, M., \& McIntyre, K. (2012). Can we reduce eating disorder risk factors in female college athletes? a randomized exploratory investigation of two peer-led interventions. Body Image, 9(1), 31-42. PubMed ID: 22019502 doi:10.1016/ j.bodyim.2011.09.005

Berga, S.L., \& Loucks, T.L. (2006). Use of cognitive behavior therapy for functional hypothalamic amenorrhea. Annals of the New York Academy of Sciences, 1092, 114-129. PubMed ID: 17308138 doi: 10.1196/annals.1365.010

Berkovich, B.E., Eliakim, A., Nemet, D., Stark, A.H., \& Sinai, T. (2016). Rapid weight loss among adolescents participating in competitive judo. International Journal of Sport Nutrition and Exercise Metabolism, 26(3), 276-284. PubMed ID: 26479490 doi:10.1123/ijsnem.2015-0196

Bhasin, S., Cunningham, G.R., Hayes, F.J., Matsumoto, A.M., Snyder, P.J., Swerdloff, R.S., \& Montori, V.M. (2010). Testosterone therapy in men with androgen deficiency syndromes: An endocrine society clinical practice guideline. The Journal of Clinical Endocrinology and Metabolism, 95(6), 2536-2559. PubMed ID: 20525905 doi: 10.1210/jc.2009-2354

Bilanin, J.E., Blanchard, M.S., \& Russek-Cohen, E. (1989). Lower vertebral bone density in male long distance runners. Medicine \& Science in Sports \& Exercise, 21(1), 66-70. PubMed ID: 2927303 doi:10.1249/00005768-198902000-00012

Blauwet, C.A., Brook, E.M., Tenforde, A.S., Broad, E., Hu, C.H., Abdu-Glass, E., \& Matzkin, E.G. (2017). Low energy availability, menstrual dysfunction, and low bone mineral density in individuals with a disability: Implications for the para athlete population. Sports Medicine, 47(9), 1697-1708. PubMed ID: 28213754 doi:10.1007/ s40279-017-0696-0

Bomba, M., Corbetta, F., Bonini, L., Gambera, A., Tremolizzo, L., Neri, F., \& Nacinovich, R. (2014). Psychopathological traits of adolescents with functional hypothalamic amenorrhea: A comparison with anorexia nervosa. Eating and Weight Disorders, 19(1), 41-48. PubMed ID: 23912931 doi:10.1007/s40519-013-0056-5

Bomba, M., Gambera, A., Bonini, L., Peroni, M., Neri, F., Scagliola, P., \& Nacinovich, R. (2007). Endocrine profiles and neuropsychologic correlates of functional hypothalamic amenorrhea in adolescents. Fertility and Sterility, 87(4), 876-885. PubMed ID: 17274991 doi:10.1016/j.fertnstert.2006.09.011
Brown, K.N., Wengreen, H.J., \& Beals, K.A. (2014). Knowledge of the female athlete triad, and prevalence of triad risk factors among female high school athletes and their coaches. Journal of Pediatric \& Adolescent Gynecology, 27(5), 278-282. PubMed ID: 25023979 doi:10.1016/j.jpag.2013.11.014

Brown, K.N., Wengreen, H.J., Beals, K.A., \& Heath, E.M. (2016). Effects of peer-education on knowledge of the female athlete triad among high school track and field athletes: A pilot study. Women in Sport and Physical Activity, 24, 1-6.

Buchholz, A., \& Pencharz, P. (2004). Energy expenditure in chronic spinal cord injury. Current Opinion in Clinical Nutrition and Metabolic Care, 7, 635-639. PubMed ID: 15534431

Burden, R.J., Morton, K., Richards, T., Whyte, G.P., \& Pedlar, C.R. (2015). Is iron treatment beneficial in, iron-deficient but non-anaemic (idna) endurance athletes? A systematic review and meta-analysis. British Journal of Sports Medicine, 49(21), 1389-1397. PubMed ID: 25361786 doi:10.1136/bjsports-2014-093624

Burke, L., \& Deakin, V. (2015). Clinical sports nutrition (5th ed.). North Ryde, Australia: McGraw-Hilll Education Australia.

Burke, L.M., Lundy, B.L., Fahrenholtz, L., \& Melin, A. (2018a). Pitfalls of conducting and interpreting estimates of energy availability in freeliving athletes. International Journal of Sport Nutrition and Exercise Metabolism, 28(4). doi:10.1123/ijsnem.2018-0142

Burke, L.M., Close, G.L., Lundy, B., Mooses, M., Morton, J.P., \& Tenforde, A.S. (2018b). Relative energy deficiency in sport in male athletes: A commentary on its presentation among selected groups of male athletes. International Journal of Sport Nutrition and Exercise Metabolism. 28(4). doi:10.1123/ijsnem.2018-0182

Cialdella-Kam, L., Guebels, C.P., Maddalozzo, G.F., \& Manore, M.M. (2014). Dietary intervention restored menses in female athletes with exercise-associated menstrual dysfunction with limited impact on bone and muscle health. Nutrients, 6(8), 3018-3039. PubMed ID: 25090245 doi:10.3390/nu6083018

Clausen, L., Lübeck, M., \& Jones, A. (2013). Motivation to change in the eating disorders: A systematic review. The International Journal of Eating Disorders, 46(8), 755-763. PubMed ID: 23847134 doi: 10.1002/eat.22156

Cobb, K.L., Bachrach, L.K., Sowers, M.F., Nieves, J.W., Greendale, G.A., Kent, K.K., ... Kelsey, J.L. (2007). The effect of oral contraceptives on bone mass and stress fractures in female runners. Medicine \& Science in Sports \& Exercise, 39(9), 1464-1473. PubMed ID: 17805075 doi:10.1249/mss.0b013e318074e532

Colantonio, A., Reg, O., Mar, W., Escobar, M., Yoshida, K., Velikonja, D., ... Cullen, N. (2010). Women's health outcomes after traumatic brain injury. Journal of Women's Health, 19(6), 1109-1116. PubMed ID: 29763080

Constantini, N. (2002). Medical concerns of the dancer. In FIMS World Congress of Sports Medicine. Budapest, Hungary.

Crosland, J., \& Boyd, C. (2014). Cerebral palsy and acquired brain injuries. In E. Broad (Ed.), Sports nutrition for paralympic athletes (pp. 91-105). Boca Rotan, FL: CRC Press.

Curry, E.J., Logan, C., Ackerman, K.E., McInnis, K.C., \& Matzkin, E.G. (2015). Female athlete triad awareness among multispecialty physicians. Sports Medicine - Open, 1(1), 38. doi:10.1186/s40798-015-0037-5

de Bruin, A.P.K. (2017). Athletes with eating disorder symptomatology, a specific population with specific needs. Current Opinion in Psychology, 16, 148-153. PubMed ID: 28813340 doi:10.1016/j.copsyc. 2017.05.009

De Souza, M.J., Hontscharuk, R., Olmsted, M.P., Kerr, G., \& Williams, N.I. (2007). Drive for thinness score is a proxy indicator of energy deficiency in exercising women. Appetite, 48(3), 359-367. PubMed ID: 17184880 doi:10.1016/j.appet.2006.10.009 
De Souza, M.J., Nattiv, A., Joy, E., Misra, M., Williams, N.I., Mallinson, R.J., .. Matheson, G. (2014). 2014 Female athlete triad coalition consensus statement on treatment and return to play of the female athlete triad: 1st International conference held in San Francisco, CA, May 2012 and 2nd international conference held in Indianapolis, IN, may 2013. British Journal of Sports Medicine, 24(2), 96-119.

De Souza, M.J., West, S.L., Jamal, S.A., Hawker, G.A., Gundberg, C.M., $\&$ Williams, N.I. (2008). The presence of both an energy deficiency and estrogen deficiency exacerbate alterations of bone metabolism in exercising women. Bone, 43(1), 140-148. PubMed ID: 18486582 doi:10.1016/j.bone.2008.03.013

De Souza, M.J., Williams, N.I., Nattiv, A., Joy, E., Misra, M., Loucks, A.B., ... Rauh, M.J. (2014). Misunderstanding the female athlete triad: Refuting the IOC consensus statement on relative energy deficiency in sport (red-s). British Journal of Sports Medicine, 48(20), 1461-1465. PubMed ID: 25037200 doi:10.1136/bjsports2014-093958

Drew, M.K., Vlahovich, N., Hughes, D., Appaneal, R., Burke, L.M., Lundy, B., ... Waddington, G. (2018). Prevalence of illness, poor mental health and sleep quality and low energy availability prior to the 2016 summer olympic games. British Journal of Sports Medicine, 52(1), 47-53. PubMed ID: 29056598 doi:10.1136/bjsports-2017098208

Drew, M.K., Vlahovich, N., Hughes, D., Appaneal, R., Peterson, K., Burke, L.M., .. . Waddington, G. (2017). A multifactorial evaluation of illness risk factors in athletes preparing for the summer olympic games. Journal of Science and Medicine in Sport, 20(8), 745-750. PubMed ID: 28385561 doi:10.1016/j.jsams.2017.02.010

Ducher, G., Turner, A.I., Kukuljan, S., Pantano, K.J., Carlson, J.L., Williams, N.I., \& De Souza, M.J. (2011). Obstacles in the optimization of bone health outcomes in the female athlete triad. Sports Medicine, 41(7), 587-607. PubMed ID: 21688870 doi:10.2165/ 11588770-000000000-00000

Dueck, C.A, Matt, K.S., Manore, M.M., \& Skinner, J.S. (1996). Treatment of athletic amenorrhea with a diet and training intervention program. International Journal of Sport Nutrition, 6(1), 24-40. PubMed ID: 8653102 doi:10.1123/ijsn.6.1.24

El Ghoch, M., Soave, F., Calugi, S., \& Dalle Grave, R. (2013). Eating disorders, physical fitness and sport performance: A systematic review. Nutrients, 5(12), 5140-5160. PubMed ID: 24352092 doi:10.3390/nu5125140

Fagerberg, P. (2018). Negative consequences of low energy availability in natural male bodybuilding: A review. International Journal of Sport Nutrition and Exercise Metabolism, 28(4). doi:10.1123/ijsnem. 2016-0332

Fairburn, C.G., \& Beglin, S.J. (1994). Assessment of eating disorders: Interview or self-report questionnaire? International Journal of Eating Disorders, 16(4), 363-370. PubMed ID: 7866415

Fairburn, C.G., Cooper, Z., \& O'Connor, M. (2008). Eating disorder examination. In C.G. Fairburn (Ed.), Cognitive behavior therapy and eating disorders, (pp. 270-308). New York, NY: Guilford Press. doi:10.1037/t03975-000

Fazeli, P.K., \& Klibanski, A. (2014). Determinants of GH resistance in malnutrition. Journal of Endocrinology, 220(3), R57-R65. PubMed ID: 24363451 doi:10.1530/JOE-13-0477

Fazeli, P.K., Wang, I.S., Miller, K.K., Herzog, D.B., Misra, M., Lee, H., ... Klibanski, A. (2014). Teriparatide increases bone formation and bone mineral density in adult women with anorexia nervosa. The Journal of Clinical Endocrinology and Metabolism, 99(4), 1322-1329. PubMed ID: 24456286 doi:10.1210/jc.2013-4105

Feldmann, J.M., Belsha, J.P., Eissa, M.A., \& Middleman, A.B. (2011). Female adolescent athletes' awareness of the connection between menstrual status and bone health. Journal of Pediatric \& Adolescent Gynecology, 24(5), 311-314. PubMed ID: 21872775 doi:10.1016/ j.jpag.2011.05.011

Fogelholm, M. (1994). Effects of bodyweight reduction on sports performance. Sports Medicine, 18(4), 249-267. PubMed ID: 7817064 doi:10.2165/00007256-199418040-00004

Fredericson, M., Chew, K., Ngo, J., Cleek, T., Kiratli, J., \& Cobb, K.L. (2007). Regional bone mineral density in male athletes: A comparison of soccer players, runners and controls. British Journal of Sports Medicine, 41(10), 664-668. PubMed ID: 17473003 doi:10.1136/ bjsm.2006.030783

Garner, D.M., \& Garfinkel, P.E. (1979). The eating attitudes test: An index of the symptoms of anorexia nervosa. Psychological Medicine, 9, 273-279. PubMed ID: 472072

Garner, D.M., Olmstead, M.P., \& Polivy, J. (1983). Development and validation of a multidimensional eating disorder inventory for anorexia nervosa and bulimia. International Journal of Eating Disorders, 2(2), 15-34. doi:10.1002/1098-108X(198321)2:2<15::AIDEAT2260020203>3.0.CO;2-6

Gaskins, A.J., Mumford, S.L., Zhang, C., Wactawski-Wende, J., Hovey, K.M., Whitcomb, B.W., . . S Schisterman, E.F. (2009). Effect of daily fiber intake on reproductive function: The biocycle study. American Journal of Clinical Nutrition, 90(4), 1061-1069. PubMed ID: 19692496 doi:10.3945/ajen.2009.27990

Geesmann, B., Gibbs, J.C., Mester, J., \& Koehler, K. (2017). Association between energy balance and metabolic hormone suppression during ultraendurance exercise. International Journal of Sports Physiology and Performance, 12(7), 984-989. PubMed ID: 27967268 doi: 10.1123/ijspp.2016-0061

Gibbs, J.C., Williams, N.I., \& De Souza, M.J. (2013). Prevalence of individual and combined components of the female athlete triad. Medicine \& Science in Sports \& Exercise, 45(5), 985-996. PubMed ID: 23247706 doi:10.1249/MSS.0b013e31827e1bdc

Gibbs, J.C., Williams, N.I., Scheid, J.L., Toombs, R.J., \& De Souza, M.J. (2011). The association of a high drive for thinness with energy deficiency and severe menstrual disturbances: Confirmation in a large population of exercising women. International Journal of Sport Nutrition and Exercise Metabolism, 21(4), 280-290. PubMed ID: 21813911

Giel, K.E., Hermann-Werner, A., Mayer, J., Diehl, K., Schneider, S., Thiel, A., \& Zipfel, S. (2016). Eating disorder pathology in elite adolescent athletes. International Journal of Eating Disorders, 49(6), 553-562. PubMed ID: 26876906 doi:10.1002/eat.22511

Goktepe, A.S., Yilmaz, B., Alaca, R., Yazicioglu, K., Mohur, H., \& Gunduz, S. (2004). Bone density loss after spinal cord injury: Elite paraplegic basketball players vs. paraplegic sedentary persons. American Journal of Physical Medicine and Rehabilitation, 83(4), 279-283. PubMed ID: 15024329 doi:10.1097/01.PHM.0000118036. 20170.6C

Golden, N.H., \& Carey, D.E. (2016). Vitamin D in health and disease in adolescents: When to screen, whom to treat, and how to treat. Adolescent Medicine: State of the Art Reviews, 27(1), 125-139. PubMed ID: 27363237

Gonzalez, E.G., Corcoran, P.J., \& Reyes, R.L. (1974). Energy expenditure in below-knee amputees: Correlation with stump length. Archives of Physical Medicine and Rehabilitation, 55(3), 111-119. PubMed ID: 4817680

Gordon, C.M., Ackerman, K.E., Berga, S.L., Kaplan, J.R., Mastorakos, G., Misra, M., ... Warren, M.P. (2017). Functional hypothalamic amenorrhea: An endocrine society clinical practice guideline. The Journal of Clinical Endocrinology \& Metabolism, 102(5), 14131439. PubMed ID: 28368518 doi:10.1210/jc.2017-00131 
Hackney, A.C., Moore, A.W., \& Brownlee, K.K. (2005). Testosterone and endurance exercise: Development of the "exercise-hypogonadal male condition". Acta Physiologica Hungarica, 92(2), 121-137. PubMed ID: 16268050 doi:10.1556/APhysiol.92.2005.2.3

Hackney, A.C., Sinning, W.E., \& Bruot, B.C. (1988). Reproductive hormonal profiles of endurance-trained and untrained males. Medicine \& Science in Sports \& Exercise, 20(1), 60-65. PubMed ID: 3343919 doi:10.1249/00005768-198802000-00009

Hagmar, M., Berglund, B., Brismar, K., \& Hirschberg, A.L. (2013). Body composition and endocrine profile of male olympic athletes striving for leanness. Clinical Journal of Sport Medicine, 23(3), 197-201. PubMed ID: 23275346 doi:10.1097/JSM.0b013e31827a8809

Harber, V.J., Petersen, S.R., \& Chilibeck, P.D. (1998). Thyroid hormone concentrations and muscle metabolism in amenorrheic and eumenorrheic athletes. Canadian Journal of Applied Physiology, 23(3), 293-306. PubMed ID: 9615871 doi:10.1139/h98-017

Heikura, I.A., Uusitalo, A.L.T., Stellingwerff, T., Bergland, D., Mero, A.A., \& Burke, L.M. (2018). Low energy availability is difficult to assess but outcomes have large impact on bone injury rates in elite distance athletes. International Journal of Sport Nutrition and Exercise Metabolism, 28(4). doi:10.1123/ijsnem.2017-0313

Hill, L.S., Reid, F., Morgan, J.F., \& Lacey, J.H. (2010). Scoff, the development of an eating disorder screening questionnaire. International Journal of Eating Disorders, 43(4), 344-351. PubMed ID: 19343793 doi:10.1002/eat.20679

Hind, K., Truscott, J.G., \& Evans, J.A. (2006). Low lumbar spine bone mineral density in both male and female endurance runners. Bone, 39(4), 880-885. PubMed ID: 16682267 doi:10.1016/j.bone.2006.03. 012

Hinton, P.S., \& Kubas, K.L. (2005). Psychosocial correlates of disordered eating in female collegiate athletes: Validation of the athlete questionnaire. Journal of American College Health, 54(3), 149-156. PubMed ID: 16335314 doi:10.3200/JACH.54.3.149-156

Hoch, A.Z., Jurva, J.W., Staton, M.A., Thielke, R., Hoffmann, R.G., Pajewski, N., \& Gutterman, D.D. (2007). Athletic amenorrhea and endothelial dysfunction. WMJ: Official Publication of the State Medical Society of Wisconsin, 106(6), 301-306. PubMed ID: 29691006

Holick, M.F., Binkley, N.C., Bischoff-Ferrari, H.A., Gordon, C.M., Hanley, D.A., Heaney, R.P., ... Weaver, C.M. (2011). Evaluation, treatment, and prevention of vitamin D deficiency: An endocrine society clinical practice guideline. The Journal of Clinical Endocrinology and Metabolism, 96(7), 1911-1930. PubMed ID: 21646368 doi:10.1210/jc.2011-0385

Hooper, D.R., Kraemer, W.J., Saenz, C., Schill, K.E., Focht, B.C., Volek, J.S., \& Maresh, C.M. (2017). The presence of symptoms of testosterone deficiency in the exercise-hypogonadal male condition and the role of nutrition. European Journal of Applied Physiology, 117(7), 1349-1357. PubMed ID: 28470410 doi:10.1007/s00421-017-3623-z

Ihle, R., \& Loucks, A.B. (2004). Dose-response relationships between energy availability and bone turnover in young exercising women. Journal of Bone and Mineral Research, 19(8), 1231-1240. PubMed ID: 15231009 doi:10.1359/JBMR.040410

Iwamoto, J., Sato, Y., Takeda, T., \& Matsumoto, H. (2011). Analysis of stress fractures in athletes based on our clinical experience. World Journal of Orthopedics, 2(1), 7-12. PubMed ID: 22474626 doi: 10.5312/wjo.v2.i1.7

Jasienska, G. (2003). Energy metabolism and the evolution of reproductive suppression in the human female. Acta Biotheoretica, 51(1), 1-18. PubMed ID: 12765249 doi:10.1023/A:1023035321162

Joy, E., Kussman, A., \& Nattiv, A. (2016). 2016 update on eating disorders in athletes: A comprehensive narrative review with a focus on clinical assessment and management. British Journal of Sports Medicine,
50(3), 154-162. PubMed ID: 26782763 doi:10.1136/bjsports-2015095735

Kilpela, L.S., Blomquist, K., Verzijl, C., Wilfred, S., Beyl, R., \& Becker, C.B. (2016). The body project 4 all: A pilot randomized controlled trial of a mixed-gender dissonance-based body image program. International Journal of Eating Disorders, 49(6), 591-602. PubMed ID: 27188688 doi:10.1002/eat.22562

Kim, B.Y., Kraus, E., Fredericson, M., Singh, S., Kussman, A., Barrack, M.T., .. Nattiv, A. (2016). Serum vitamin D levels are inversely associated with time lost to bone stress injury in a cohort of NCAA division I distance runners. Clinical Journal of Sport Medicine, 26(2), e61.

Koehler, K., De Souza, M.J., \& Williams, N.I. (2017). Less-than-expected weight loss in normal-weight women undergoing caloric restriction and exercise is accompanied by preservation of fat-free mass and metabolic adaptations. European Journal of Clinical Nutrition, 71(3), 365-371. PubMed ID: 27782114 doi:10.1038/ejen.2016.203

Koehler, K., Hoerner, N.R., Gibbs, J.C., Zinner, C., Braun, H., De Souza, M.J., \& Schaenzer, W. (2016). Low energy availability in exercising men is associated with reduced leptin and insulin but not with changes in other metabolic hormones. Journal of Sports Sciences, 34(20), 1921-1929. PubMed ID: 26852783 doi:10.1080/02640414.2016. 1142109

Kong, P., \& Harris, L.M. (2015). The sporting body: Body image and eating disorder symptomatology among female athletes from leanness focused and nonleanness focused sports. Journal of Psychology: Interdisciplinary and Applied, 149(2), 141-160. doi:10.1080/ 00223980.2013 .846291

Kopp-Woodroffe, S.A., Manore, M.M., Dueck, C.A., Skinner, J.S., \& Matt, K.S. (1999). Energy and nutrient status of amenorrheic athletes participating in a diet and exercise training intervention program. International Journal of Sport Nutrition and Exercise Metabolism, 9(1), 70-88. PubMed ID: 10200061

Krempien, J.L., \& Barr, S.I. (2011). Risk of nutrient inadequacies in elite Canadian athletes with spinal cord injury. International Journal of Sport Nutrition and Exercise Metabolism, 21(5), 417-425. PubMed ID: 21904002

Krempien, J.L., \& Barr, S.I. (2012). Eating attitudes and behaviours in elite Canadian athletes with a spinal cord injury. Eating Behaviors, 13(1), 36-41. PubMed ID: 22177393 doi:10.1016/j.eatbeh.2011. 11.005

Krentz, E.M., \& Warschburger, P. (2013). A longitudinal investigation of sports-related risk factors for disordered eating in aesthetic sports. Scandinavian Journal of Medicine and Science in Sports, 23(3), 303-310. PubMed ID: 22093018 doi:10.1111/j.1600-0838. 2011.01380.x

Kroshus, E., Fischer, A.N., \& Nichols, J.F. (2015). Assessing the awareness and behaviors of U.S. high school nurses with respect to the female athlete triad. The Journal of School Nursing?: The Official Publication of the National Association of School Nurses, 31(4), 272-279. PubMed ID: 29720050 doi:10.1177/1059840514563760

Kroshus, E., Sherman, R.T., Thompson, R.A., Sossin, K., \& Austin, S.B. (2014). Gender differences in high school coaches' knowledge, attitudes, and communication about the female athlete triad. Eating Disorders, 22(3), 193-208. PubMed ID: 24456303 doi:10.1080/ 10640266.2013.874827

Lantzouni, E., Frank, G.R., Golden, N.H., \& Shenker, R.I. (2002). Reversibility of growth stunting in early onset anorexia nervosa: A prospective study. Journal of Adolescent Health, 31(2), 162-165. PubMed ID: 12127386 doi:10.1016/S1054-139X(02)00342-7

Lappe, J.M., Stegman, M.R., \& Recker, R.R. (2001). The impact of lifestyle factors on stress fractures in female army recruits. Osteoporosis 
International, 12(1), 35-42. PubMed ID: 11305081 doi:10. 1007/s001980170155

Laughlin, G.A., \& Yen, S.S.C. (1996). Nutritional and endocrinemetabolic aberrations in amenorrheic athletes. Journal of Clinical Endocrinology and Metabolism, 81(12), 4301-4309. PubMed ID: 8954031

Levine, J.A. (2005). Measurement of energy expenditure. Public Health Nutrition, 8(7A), 1123-1132. PubMed ID: 16277824 doi:10.1079/ PHN2005800

Lieberman, J.L., De Souza, M.J., Wagstaff, D.A., \& Williams, N.I. (2018). Menstrual disruption with exercise is not linked to an energy availability threshold. Medicine \& Science in Sports \& Exercise, 50(3), 551561. PubMed ID: 29023359 doi:10.1249/MSS.0000000000001451

Ljungqvist, A., Jenoure, P., Engebretsen, L., Alonso, J.M., Bahr, R., Clough, A., ... Thill, C. (2009). The International Olympic Committee (IOC) consensus statement on periodic health evaluation of elite athletes, March 2009. British Journal of Sports Medicine, 43, 631643. PubMed ID: 19734496 doi:10.1097/JSM.0b013e3181b7332c

Logue, D., Madigan, S.M., Delahunt, E., Heinen, M., Mc Donnell, S.J., \& Corish, C.A. (2018). Low energy availability in athletes: A review of prevalence, dietary patterns, physiological health, and sports performance. Sports Medicine, 48(1), 73-96. PubMed ID: 28983802 doi: 10.1007/s40279-017-0790-3

Lopez, L.M., Chen, M., Mullins Long, S., Curtis, K.M., \& Helmerhorst, F.M. (2015). Steroidal contraceptives and bone fractures in women: Evidence from observational studies. The Cochrane Database of Systematic Reviews, (7), CD009849. doi:10.1002/14651858.CD009849.pub3

Lopez, L.M., Grimes, D.A., Schulz, K.F., Curtis, K.M., \& Chen, M. (2014). Steroidal contraceptives: Effect on bone fractures in women. The Cochrane Database of Systematic Reviews, (6), CD006033. doi:10.1002/14651858.CD006033.pub5

Loucks, A.B. (2007). Low energy availability in the marathon and other endurance sports. Sports Medicine, 37(4), 348-352. doi:10.2165/ 00007256-200737040-00019

Loucks, A.B., \& Heath, E.M. (1994). Induction of low-t3 syndrome in exercising women occurs at a threshold of energy availability. American Journal of Physiology - Regulatory Integrative \& Comparative Physiology, 266, R817-R823. PubMed ID: 8160876 doi: 10.3945/ajcn.114.092189

Loucks, A.B., Kiens, B., \& Wright, H.H. (2011). Energy availability in athletes. Journal of Sports Sciences, 29(Suppl. 1), S7-S15. PubMed ID: 21793767 doi:10.1080/02640414.2011.588958

Loucks, A.B., \& Thuma, J.R. (2003). Luteinizing hormone pulsatility is disrupted at a threshold of energy availability in regularly menstruating women. Journal of Clinical Endocrinology and Metabolism, 88(1), 297-311. PubMed ID: 12519869 doi:10.1210/jc.2002-020369

MacConnie, S.E., Barkan, A., Lampman, R.M., Schork, M.A., \& Beitins, I.Z. (1986). Decreased hypothalamic gonadotropin-releasing hormone secretion in male marathon runners. The New England Journal of Medicine, 315(7), 411-417. PubMed ID: 3090437 doi:10.1056/ NEJM198608143150702

Mallinson, R.J., Williams, N.I., Olmsted, M.P., Scheid, J.L., Riddle, E.S., \& De Souza, M.J. (2013). A case report of recovery of menstrual function following a nutritional intervention in two exercising women with amenorrhea of varying duration. Journal of the International Society of Sports Nutrition, 10, 34. PubMed ID: 23914797 doi:10. 1186/1550-2783-10-34

Manore, M.M., Patton-Lopez, M.M., Meng, Y., \& Wong, S.S. (2017). Sport nutrition knowledge, behaviors and beliefs of high school soccer players. Nutrients, 9(4). doi:10.3390/nu9040350

Marcus, M.D., Loucks, T.L., \& Berga, S.L. (2001). Psychological correlates of functional hypothalamic amenorrhea. Fertility and Sterility,
76(2), 310-316. PubMed ID: 11476778 doi:10.1016/S0015-0282 (01)01921-5

Martinsen, M., Bahr, R., BØrresen, R., Holme, I., Pensgaard, A.M., \& Sundgot-Borgen, J. (2014). Preventing eating disorders among young elite athletes: A randomized controlled trial. Medicine \& Science in Sports \& Exercise, 46(3), 435-447. PubMed ID: 24549033 doi: 10.1249/MSS.0b013e3182a702fc

Martinsen, M., Bratland-Sanda, S., Eriksson, A.K., \& Sundgot-Borgen, J. (2010). Dieting to win or to be thin? A study of dieting and disordered eating among adolescent elite athletes and non-athlete controls. British Journal of Sports Medicine, 44(1), 70-76. PubMed ID: 20026698 doi:10.1136/bjsm.2009.068668

Martinsen, M., Sherman, R.T., Thompson, R.A., \& Sundgot-Borgen, J. (2015). Coaches' knowledge and management of eating disorders: A randomized controlled trial. Medicine \& Science in Sports \& Exercise, 47(5), 1070-1078. PubMed ID: 25202842 doi:10.1249/MSS. 0000000000000489

Martinsen, M., \& Sundgot-Borgen, J. (2013). Higher prevalence of eating disorders among adolescent elite athletes than controls. Medicine \& Science in Sports \& Exercise, 45(6), 1188-1197. PubMed ID: 23274604 doi:10.1249/MSS.0b013e318281a939

McColl, E.M., Wheeler, G.D., Gomes, P., Bhambhani, Y., \& Cumming, D.C. (1989). The effects of acute exercise on pulsatile LH release in high-mileage male runners. Clinical Endocrinology, 31(5), 617-621. PubMed ID: 2627755 doi:10.1111/j.1365-2265.1989. tb01286.x

McNulty, K.Y., Adams, C.H., Anderson, J.M., \& Affenito, S.G. (2001). Development and validation of a screening tool to identify eating disorders in female athletes. Journal of the American Dietetic Association, 101(8), 886-892. PubMed ID: 11501862 doi:10.1016/ S0002-8223(01)00218-8

Melin, A., \& Lundy, B. (2015). Measuring energy availability. In L. Burke, \& V. Deakin (Eds.), Clinical sports nutrition (5th ed., pp. 146-157). Sydney, Australia: McGraw-Hilll.

Melin, A., Tornberg, Å.B., Skouby, S., Faber, J., Ritz, C., Sjödin, A., \& Sundgot-Borgen, J. (2014). The leaf questionnaire: A screening tool for the identification of female athletes at risk for the female athlete triad. British Journal of Sports Medicine, 48(7), 540-545. PubMed ID: 24563388 doi:10.1136/bjsports-2013-093240

Melin, A., Tornberg, Å.B., Skouby, S., Møller, S.S., Faber, J., SundgotBorgen, J., \& Sjödin, A. (2016). Low-energy density and high fiber intake are dietary concerns in female endurance athletes. Scandinavian Journal of Medicine and Science in Sports, 26(9), 1060-1071. doi:10.1111/sms.12516

Melin, A., Tornberg, Å.B., Skouby, S., Møller, S.S., Sundgot-Borgen, J., Faber, J., ... Sjödin, A. (2015). Energy availability and the female athlete triad in elite endurance athletes. Scandinavian Journal of Medicine and Science in Sports, 25(5), 610-622. PubMed ID: 24888644 doi:10.1111/sms.12261

Michopoulos, V., Mancini, F., Loucks, T.L., \& Berga, S.L. (2013). Neuroendocrine recovery initiated by cognitive behavioral therapy in women with functional hypothalamic amenorrhea: A randomized, controlled trial. Fertility and Sterility, 99(7), 2084-2091.e1. PubMed ID: 23507474 doi:10.1016/j.fertnstert.2013.02.036

Miller, S., Kukuljan, S., Turner, A.I., van der Pligt, P., \& Ducher, G. (2012). Energy deficiency, menstrual disturbances and low bone mass: What do Australian exercising females know about the female athlete triad? International Journal of Sport Nutrition and Exercise Metabolism, 22(2), 131-138. PubMed ID: 22465866

Misra, M. (2014). Neuroendocrine mechanisms in athletes. Handbook of Clinical Neurology, 124, 373-386. PubMed ID: 25248600 doi: 10.1016/B978-0-444-59602-4.00025-3 
Misra, M., Katzman, D.K., Miller, K.K., Mendes, N., Snelgrove, D., Russell, M., ... Klibanski, A. (2011). Physiologic estrogen replacement increases bone density in adolescent girls with anorexia nervosa. Journal of Bone and Mineral Research, 26(10), 2430-2438. PubMed ID: 21698665 doi:10.1002/jbmr.447

Modan-Moses, D., Yaroslavsky, A., Kochavi, B., Toledano, A., Segev, S., Balawi, F., ... Stein, D. (2012). Linear growth and final height characteristics in adolescent females with anorexia nervosa. PLoS ONE, 7(9), 1-8. doi:10.1371/journal.pone.0045504

Modan-Moses, D., Yaroslavsky, A., Novikov, I., Segev, S., Toledano, A., Miterany, E., \& Stein, D. (2003). Stunting of growth as a major feature of anorexia nervosa in male adolescents. Pediatrics, 111(2), 270-276. PubMed ID: 12563050 doi:10.1542/peds.111.2.270

Mooses, M., \& Hackney, A.C. (2017). Anthropometrics and body composition in East African runners: Potential impact on performance. International Journal of Sport Nutrition and Exercise Metabolism, 12(4), 422-430. doi:10.1123/ijspp.2015-0012

Moreira, C.A., \& Bilezikian, J.P. (2017). Stress fractures: Concepts and therapeutics. Journal of Clinical Endocrinology and Metabolism, 102(2), 525-534. PubMed ID: 27732325 doi:10.1210/jc.20162720

Morel, J., Combe, B., Francisco, J., \& Bernard, J. (2001). Bone mineral density of 704 amateur sportsmen involved in different physical activities. Osteoporosis International, 12(2), 152-157. PubMed ID: 11303716 doi:10.1007/s001980170148

Mountjoy, M., Costa, A., Budgett, R., Dvorak, J., Engebretsen, L., Miller, S., . . Carr, J. (2018). Health promotion through sport: International sport federations' priorities, actions and opportunities. British Journal of Sports Medicine, 52(1), 54-60. PubMed ID: 28701361

Mountjoy, M., Sundgot-Borgen, J., Burke, L.M., Carter, S., Constantini, N., Lebrun, C., ... Ackerman, K.E. (2015). Relative energy deficiency in sport (red-s) clinical assessment tool (cat). British Journal of Sports Medicine, 49(7), 421-423. PubMed ID: 25896450 doi: 10.1136/bjsports-2014-094559

Mountjoy, M., Sundgot-Borgen, J., Burke, L.M., Carter, S., Constantini, N., Lebrun, C., ... Ljungqvist, A. (2014). The IOC consensus statement: Beyond the female athlete triad-relative energy deficiency in sport (red-s). British Journal of Sports Medicine, 48(7), 491-497. PubMed ID: 24620037 doi:10.1136/bjsports-2014-093502

Mountjoy, M., Sundgot-Borgen, J., Burke, L.M., Carter, S., Constantini, N., Lebrun, C., . . L Ljungqvist, A. (2015). Authors' 2015 additions to the IOC consensus statement: Relative energy deficiency in sport (red-s). British Journal of Sports Medicine, 49(7), 417-420. doi:10. 1136/bjsports-2014-093502

Muia, E.N., Wright, H.H., Onywera, V.O., \& Kuria, E.N. (2016). Adolescent elite Kenyan runners are at risk for energy deficiency, menstrual dysfunction and disordered eating. Journal of Sports Sciences, 34(7), 598-606. PubMed ID: 26153433 doi:10.1080/ 02640414.2015 .1065340

Mukeshi, M., \& Thairu, K. (1993). Nutrition and body build: A Kenyan review. World Review of Nutrition and Dietetics, 72, 218-226. PubMed ID: 8506705

Mukherjee, S., Chand, V., Wong, X.X., Choong, P.P., Lau, V.S.M., Wang, S.C.L., ... Ng, K.W. (2016). Perceptions, awareness and knowledge of the female athlete triad amongst coaches - are we meeting the expectations for athlete safety? International Journal of Sports Science and Coaching, 11(4), 545-551. doi:10.1177/17479541 16654781

Myburgh, K.H., Hutchins, J., Fataar, A.B., Hough, S.F., \& Noakes, T.D. (1990). Low bone density is an etiologic factor for stress fractures in athletes. Annals of Internal Medicine, 113(10), 754-759. PubMed ID: 1978620 doi:10.7326/0003-4819-113-10-754
Nattiv, A., Loucks, A.B., Manore, M.M., Sanborn, C.F., Sundgot-Borgen, J., \& Warren, M.P. (2007). The female athlete triad. Medicine \& Science in Sports \& Exercise, 39(10), 1867-1882. PubMed ID: 17909417 doi:10.1249/mss.0b013e318149f111

Nichols, J.F., \& Rauh, M.J. (2011). Longitudinal changes in bone mineral density in male master cyclists and nonathletes. Journal of Strength and Conditioning Research, 25(3), 727-734. PubMed ID: 20581701 doi:10.1519/JSC.0b013e3181c6a116

Nieves, J.W., Melsop, K., Curtis, M., Kelsey, J.L., Bachrach, L.K., Greendale, G.A., ... Sainani, K.L. (2010). Nutritional factors that influence change in bone density and stress fracture risk among young female cross-country runners. Physical Medicine and Rehabilitation, 2(8), 740-750. doi:10.1016/j.pmrj.2010.04.020

Norris, M.L., Harrison, M.E., Isserlin, L., Robinson, A., Feder, S., \& Sampson, M. (2016). Gastrointestinal complications associated with anorexia nervosa: A systematic review. International Journal of Eating Disorders, 49(3), 216-237. PubMed ID: 26407541 doi:10. 1002/eat.22462

O’Donnell, E., Goodman, J.M., \& Harvey, P.J. (2011). Cardiovascular consequences of ovarian disruption: A focus on functional hypothalamic amenorrhea in physically active women. Journal of Clinical Endocrinology and Metabolism, 96(12), 3638-3648. doi:10.1210/ jc.2011-1223

O’Donnell, E., Goodman, J.M., Mak, S., Murai, H., Morris, B.L., Floras, J.S., \& Harvey, P.J. (2015). Discordant orthostatic reflex reninangiotensin and sympathoneural responses in premenopausal exercising-hypoestrogenic women. Hypertension, 65(5), 1089-1095. doi:10.1161/HYPERTENSIONAHA.114.04976

Onywera, V., Kiplamai, F., Tuitoek, P., Boit, M., \& Pitsiladis, Y. (2004). Food and macronutrient intake of elite Ethiopian distance runners. Journal of the International Society of Sports Nutrition, 14(2), 709-719.

Pantano, K.J. (2006). Current knowledge, perceptions, and interventions used by collegiate coaches in the U.S. regarding the prevention and treatment of the female athlete triad. North American Journal of Sports Physical Therapy?: NAJSPT, 1(4), 195-207. PubMed ID: 21655385

Pantano, K.J. (2017). Knowledge, attitude, and skill of high school coaches with regard to the female athlete triad. Journal of Pediatric \& Adolescent Gynecology, 30(5), 540-545. PubMed ID: 27721026 doi:10.1016/j.jpag.2016.09.013

Papageorgiou, M., Dolan, E., Elliott-Sale, K.J., \& Sale, C. (2018). Reduced energy availability: Implications for bone health in physically active populations. European Journal of Nutrition, 57(3), 847-859. doi:10.1007/s00394-017-1498-8

Papageorgiou, M., Elliott-Sale, K.J., Parsons, A., Tang, J.C.Y., Greeves, J.P., Fraser, W.D., \& Sale, C. (2017). Effects of reduced energy availability on bone metabolism in women and men. Bone, 105, 191-199. PubMed ID: 28847532 doi:10.1016/j.bone.2017.08.019

Pernick, Y., Nichols, J.F., Rauh, M.J., Kern, M., Ji, M., Lawson, M.J., \& Wilfley, D.E. (2006). Disordered eating among a multi-racial/ethnic sample of female high-school athletes. Journal of Adolescent Health, 38(6), 689-695. PubMed ID: 16730597 doi:10.1016/j.jadohealth. 2005.07.003

Petkus, D.L., Murray-Kolb, L.E., \& De Souza, M.J. (2017). The unexplored crossroads of the female athlete triad and iron deficiency: A narrative review. Sports Medicine, 47(9), 1721-1737. PubMed ID: 28290159 doi:10.1007/s40279-017-0706-2

Petrie, T., Galli, N., Greenleaf, C., Reel, J., \& Carter, J. (2014). Psychosocial correlates of bulimic symptomatology among male athletes. Psychology of Sport and Exercise, 15(6), 680-687. doi:10.1016/ j.psychsport.2013.09.002 
Pinheiro Volp, A.C., Esteves de Oliveira, F.C., Duarte Moreira Alves, R., Esteves, E.A., \& Bressan, J. (2011). Energy expenditure: Components and evaluation methods. Nutricion Hospitalaria: Organo Oficial de La Sociedad Espanola de Nutricion Parenteral Y Enteral, 26(3), 430-440. PubMed ID: 29756987 doi:10.3305/nh.2011.26.3.5181

Plateau, C.R., Arcelus, J., Leung, N., \& Meyer, C. (2017). Female athlete experiences of seeking and receiving treatment for an eating disorder. Eating Disorders, 25(3), 273-277. PubMed ID: 28051927 doi:10. 1080/10640266.2016.1269551

Plateau, C.R., McDermott, H.J., Arcelus, J., \& Meyer, C. (2013). Identifying and preventing disordered eating among athletes. What can we learn from coaches? Appetite, 71, 483. doi:10.1016/j.appet.2013.06.052

Price, M. (2010). Energy expenditure and metabolism during exercise in persons with a spinal cord injury. Sports Medicine, 40(8), 681-696. PubMed ID: 20632738 doi:10.2165/11531960-000000000-00000

Quah, Y.V., Poh, B.K., Ng, L.O., \& Noor, M.I. (2009). The female athlete triad among elite Malaysian athletes: Prevalence and associated factors. Asia Pacific Journal of Clinical Nutrition, 18(2), 200-208. PubMed ID: 19713179

Ranganathan, P., Kumar, R.G., Davis, K., McCullough, E.H., Berga, S.L., \& Wagner, A.K. (2016). Longitudinal sex and stress hormone profiles among reproductive age and post-menopausal women after severe TBI: A case series analysis. Brain Injury, 30(4), 452-461. PubMed ID: 26963638 doi:10.3109/02699052.2016.1144081

Rauh, M.J., Nichols, J.F., \& Barrack, M.T. (2010). Relationships among injury and disordered eating, menstrual dysfunction, and low bone mineral density in high school athletes: A prospective study. Journal of Athletic Training, 45(3), 243-252. PubMed ID: 20446837 doi: 10.4085/1062-6050-45.3.243

Reed, J.L., De Souza, M.J., Kindler, J.M., \& Williams, N.I. (2014). Nutritional practices associated with low energy availability in division i female soccer players. Journal of Sports Sciences, 32(16), 1499-1509. PubMed ID: 24787233 doi:10.1080/02640414.2014. 908321

Reed, J.L., De Souza, M.J., Mallinson, R.J., Scheid, J.L., \& Williams, N.I. (2015). Energy availability discriminates clinical menstrual status in exercising women. Journal of the International Society of Sports Nutrition, 12(1), 1-11. doi:10.1186/s12970-015-0072-0

Rhea, D.J. (1999). Eating disorder behaviors of ethnically diverse urban female adolescent athletes and non-athletes. Journal of Adolescent, 22(3), 379-88.

Rickenlund, A., Eriksson, M.J., Schenck-Gustafsson, K., \& Hirschberg, A.L. (2005). Amenorrhea in female athletes is associated with endothelial dysfunction and unfavorable lipid profile. Journal of Clinical Endocrinology and Metabolism, 90(3), 1354-1359. PubMed ID: 15572426 doi:10.1210/jc.2004-1286

Ripley, D.L., Harrison-Felix, C., Sendroy-Terrill, M., Cusick, C.P., Dannels-McClure, A., \& Morey, C. (2008). The impact of female reproductive function on outcomes after traumatic brain injury. Archives of Physical Medicine and Rehabilitation, 89(6), 10901096. PubMed ID: 18503804 doi:10.1016/j.apmr.2007.10.038

Ruohola, J.P., Laaksi, I., Ylikomi, T., Haataja, R., Mattila, V.M., Sahi, T., ... Pihlajamäki, H. (2006). Association between serum 25(oh)d concentrations and bone stress fractures in finnish young men. Journal of Bone and Mineral Research, 21(9), 1483-1488. PubMed ID: 16939407 doi:10.1359/jbmr.060607

Sacheck, J.M., Van Rompay, M.I., Chomitz, V.R., Economos, C.D., Eliasziw, M., Goodman, E., ... Holick, M.F. (2017). Impact of three doses of vitamin $\mathrm{d} 3$ on serum 25 (oh) d deficiency and insufficiency in at-risk schoolchildren. The Journal of Clinical Endocrinology and Metabolism, 102(12), 4496-4505. PubMed ID: 29029097
Sansone, R.A., \& Sansone, L.A. (2007). Eating disorders and psychiatric co-morbidity: prevalence and treatment modifications. In J. Yager \& P.S. Power (Eds.), Clinical manual of eating disorders (1st ed., pp. 79-112). Washington, DC: American Psychiatric Publishing Inc.

Shanmugam, V., Jowett, S., \& Meyer, C. (2014). Interpersonal difficulties as a risk factor for athletes' eating psychopathology. Scandinavian Journal of Medicine \& Science in Sports, 24(2), 469-476. PubMed ID: 23992547 doi:10.1111/sms.12109

Sherk, V.D., Bemben, M.G., \& Bemben, D.A. (2008). BMD and bone geometry in transtibial and transfemoral amputees. Journal of Bone and Mineral Research, 23(9), 1449-1457. PubMed ID: 18410229 doi:10.1359/jbmr.080402

Shimizu, K., Suzuki, N., Nakamura, M., Aizawa, K., Imai, T., Suzuki, S., ... Akama, T. (2012). Mucosal immune function comparison between amenorrheic and eumenorrheic distance runners. Journal of Strength \& Conditioning Research, 26(5), 1402-1406. PubMed ID: 22516912 doi:10.1519/JSC.0b013e31822e7a6c

Silva, M.R., \& Paiva, T. (2016). Poor precompetitive sleep habits, nutrients' deficiencies, inappropriate body composition and athletic performance in elite gymnasts. European Journal of Sport Science, 16(6), 726-735. PubMed ID: 26505326 doi:10.1080/17461391.2015. 1103316

Spaulding-Barclay, M.A., Stern, J., \& Mehler, P.S. (2016). Cardiac changes in anorexia nervosa. Cardiology in the Young, 26(4), 623-628. PubMed ID: 26763203 doi:10.1017/S104795111500267X

Steiner, H., Pyle, R.P., Brassington, G.S., Matheson, G., \& King, M. (2003). The college health related information survey (c.h.r.i.s.-73): A screen for college student athletes. Child Psychiatry and Human Development, 34(2), 97-109. PubMed ID: 14617944 doi:10.1023/A: 1027389923666

Stewart, A.D., \& Hannan, J. (2000). Total and regional bone density in male runners, cyclists, and controls. Medicine \& Science in Sports \& Exercise, 32(8), 1373-1377. PubMed ID: 10949001 doi:10.1097/ 00005768-200008000-00003

Stice, E., South, K., \& Shaw, H. (2012). Future directions in etiologic, prevention, and treatment research for eating disorders. Journal of Clinical Child and Adolescent Psychology, 41(6), 845-855. PubMed ID: 23057638 doi:10.1080/15374416.2012.728156

Stirling, A., \& Kerr, G. (2012). Perceived vulnerabilities of female athletes to the development of disordered eating behaviours. European Journal of Sport Science, 12(3), 262-273. doi:10.1080/17461391. 2011.586437

Sundgot-Borgen, J. (1993). Prevalence of eating disorders in elite female athletes. International Journal of Sport Nutrition, 3(1), 29-40. PubMed ID: 8499936 doi:10.1123/ijsn.3.1.29

Sundgot-Borgen, J. (1994). Risk and trigger factors for the development of eating disorders in female elite athletes. Medicine \& Science in Sports \& Exercise, 26(4), 414-419. PubMed ID: 8201895 doi:10.1249/ 00005768-199404000-00003

Sundgot-Borgen, J., \& Torstveit, M.K. (2004). Prevalence of eating disorders in elite athletes is higher than in the general population. Clinical Journal of Sport Medicine, 14(1), 25-32. PubMed ID: 14712163 doi:10.1097/00042752-200401000-00005

Sykora, C., Grilo, C.M., Wilfley, D.E., \& Brownell, K.D. (1993). Eating, weight, and dieting disturbances in male and female lightweight and heavyweight rowers. International Journal of Eating Disorders, 14(2), 203-211. PubMed ID: 8401553

Tam, N., Santos-Concejero, J., Tucker, R., Lamberts, R.P., \& Micklesfield, L.K. (2018). Bone health in elite Kenyan runners. Journal of Sports Sciences, 36(4), 456-461. PubMed ID: 28406358 doi:10.1080/ 02640414.2017 .1313998 
Tarnopolsky, M.A., Zawada, C., Richmond, L.B., Carter, S., Shearer, J., Graham, T., \& Phillips, S.M. (2001). Gender differences in carbohydrate loading are related to energy intake. Journal of Applied Physiology, 91(1), 225-230. PubMed ID: 11408434

Temme, K.E., \& Hoch, A.Z. (2013). Recognition and rehabilitation of the female athlete triad/tetrad: A multidisciplinary approach. Current Sports Medicine Reports, 12(3), 190-199. PubMed ID: 23669090

Temme, K.E., Hoch, A.Z., Jonardi, M., \& Noon, M.L. (2013). Prevalence of the female athlete triad and effect of a peer-based mentoring program on triad knowledge in high school girls. Clinical Journal of Sport Medicine, 23(2), 134-135.

Tenforde, A.S., Barrack, M.T., Nattiv, A., \& Fredericson, M. (2016). Parallels with the female athlete triad in male athletes. Sports Medicine, 46(2), 171-182. PubMed ID: 26497148 doi:10.1007/s40279015-0411-y

Tenforde, A.S., Carlson, J.L., Chang, A., Sainani, K.L., Shultz, R., Kim, J.H., . . Fredericson, M. (2017). Association of the female athlete triad risk assessment stratification to the development of bone stress injuries in collegiate athletes. American Journal of Sports Medicine, 45(2), 302-310. PubMed ID: 28038316 doi:10.1177/ 0363546516676262

Tenforde, A.S., Fredericson, M., Sayres, L.C., Cutti, P., \& Sainani, K.L. (2015). Identifying sex-specific risk factors for low bone mineral density in adolescent runners. American Journal of Sports Medicine, 43(6), 1494-1504. PubMed ID: 25748470 doi:10.1177/ 0363546515572142

Thein-Nissenbaum, J.M., Carr, K.E., Hetzel, S., \& Dennison, E. (2014). Disordered eating, menstrual irregularity, and musculoskeletal injury in high school athletes: A comparison of oral contraceptive pill users and nonusers. Sports Health, 6(4), 313-320. PubMed ID: 24982703

Thiemann, P., Legenbauer, T., Vocks, S., Platen, P., Auyeung, B., \& Herpertz, S. (2015). Eating disorders and their putative risk factors among female German professional athletes. European Eating Disorders Review, 23(4), 269-276. PubMed ID: 25828261 doi:10. 1002/erv. 2360

Thompson, R.A., \& Sherman, R.T. (2011). Eating disorders in sport. New York, NY: Routledge.

Thralls, K.J., Nichols, J.F., Barrack, M.T., Kern, M., \& Rauh, M.J. (2016). Body mass-related predictors of the female athlete triad among adolescent athletes. International Journal of Sport Nutrition and Exercise Metabolism, 26(1), 17-25. PubMed ID: 26252427 doi:10. 1123/ijsnem.2015-0072

Tornberg, Å.B., Melin, A., Koivula, F.M., Johansson, A., Skouby, S., Faber, J., \& Sjödin, A. (2017). Reduced neuromuscular performance in amenorrheic elite endurance athletes. Medicine \& Science in Sports \& Exercise, 49(12), 2478-2485. PubMed ID: 28723842

Torres-McGehee, T.M., Pritchett, K.L., Zippel, D., Minton, D.M., Cellamare, A., \& Sibilia, M. (2012). Sports nutrition knowledge among collegiate athletes, coaches, athletic trainers, and strength and conditioning specialists. Journal of Athletic Training, 47(2), 205-211. PubMed ID: 22488287

Troy, K., Hoch, A.Z., \& Stavrakos, J.E. (2006). Awareness and comfort in treating the female athlete triad: Are we failing our athletes? Wesleyan Music Journal, 105(7), 21-24.
U.S. Department of Agriculture. (2011). USDA national nutrient database for standard reference. Retrieved from http://www.ars.usda.gov/ba/ bhnrc/ndl

U.S. Department of Health and Human Services. (2015). 2015-2020 Dietary guidelines for Americans. Washington, DC: United States Department of Agriculture.

Valliant, M.W., Pittman Emplaincourt, H., Kieckhaefer Wenzel, R., \& Garner, B.H. (2012). Nutrition education by a registered dietitian improves dietary intake and nutrition knowledge of a NCAA female volleyball team. Nutrients, 4(6), 506-516. PubMed ID: 22822449

Vanheest, J.L., Rodgers, C.D., Mahoney, C.E., \& De Souza, M.J. (2014). Ovarian suppression impairs sport performance in junior elite female swimmers. Medicine \& Science in Sports \& Exercise, 46(1), 156-166. PubMed ID: 23846160 doi:10.1249/MSS.0b013 e3182a32b72

Viner, R.T., Harris, M., Berning, J.R., \& Meyer, N. (2015). Energy availability and dietary patterns of adult male and female competitive cyclists with lower than expected bone mineral density. International Journal of Sport Nutrition and Exercise Metabolism, 25(6), 594-602. PubMed ID: 26131616

Vo, M., Accurso, E.C., Goldschmidt, A.B., \& Le Grange, D. (2017). The impact of DSM-5 on eating disorder diagnoses. International Journal of Eating Disorders, 50(5), 578-581. PubMed ID: 27862127 doi: 10.1002/eat.22628

Wade, G.N., \& Jones, J.E. (2004). Neuroendocrinology of nutritional infertility. American Journal of Physiology-Regulatory, Integrative and Comparative Physiology, 287(6), R1277-R1296. PubMed ID: 15528398

Waters, D.L., Qualls, C.R., Dorin, R., Veldhuis, J.D., \& Baumgartner, R.N. (2001). Increased pulsatility, process irregularity, and nocturnal trough concentrations of growth hormone in amenorrheic compared to eumenorrheic athletes. Journal of Clinical Endocrinology and Metabolism, 86(3), 1013-1019. PubMed ID: 11238479 doi:10.1210/ jc.86.3.1013

Williams, N.I., Leidy, H.J., Hill, B.R., Lieberman, J.L., Legro, R.S., \& De Souza, M.J. (2015). Magnitude of daily energy deficit predicts frequency but not severity of menstrual disturbances associated with exercise and caloric restriction. American Journal of Physiology. Endocrinology and Metabolism, 308(1), E29-E39. PubMed ID: 25352438 doi:10.1152/ajpendo.00386.2013

Wilson, G., Hawken, M.B., Poole, I., Sparks, A., Bennett, S., Drust, B., ... Close, G.L. (2014). Rapid weight-loss impairs simulated riding performance and strength in jockeys: Implications for makingweight. Journal of Sports Sciences, 32(4), 383-391. PubMed ID: 24015787

Wilson, G., Hill, J., Sale, C., Morton, J.P., \& Close, G.L. (2015). Elite male flat jockeys display lower bone density and lower resting metabolic rate than their female counterparts: Implications for athlete welfare. Applied Physiology, Nutrition, and Metabolism, 40(12), 1318-1320. PubMed ID: 26566241 doi:10.1139/apnm-2015-0354

Woods, A.L., Garvican-Lewis, L.A., Lundy, B., Rice, A.J., \& Thompson, K.G. (2017). New approaches to determine fatigue in elite athletes during intensified training: Resting metabolic rate and pacing profile. PLoS ONE, 12(3), 1-17. doi:10.1371/journal.pone.0173807 